\title{
SYMBOLISM AND INCOMMENSURABILITY IN CIVIL SANCTIONING: DECISION MAKERS AS GOAL MANAGERS*
}

\author{
Jennifer K. Robbennolt, John M. Darley \& Robert J. MacCoun ${ }^{\dagger}$
}

\section{INTRODUCTION}

Factfinders in civil cases must often make a constellation of decisions, such as assigning responsibility and blame, making compensation and (sometimes) giving out punishment. These decisions are likely to evoke numerous social and moral concerns and, therefore, inevitably implicate a variety of instrumental and symbolic goals. We argue that descriptions of legal decision making that fail to consider the psychological interplay among these different goals are likely to come up short in their efforts to explicate the ways in which jurors and other factfinders make decisions in civil cases. Instead, we suggest that decision making in civil cases can profitably be thought of as a process by which decision makers attempt to maximally satisfy a wide variety of goals in parallel.

Rights Reserved.

†ennifer K. Robbennolt, Associate Professor of Law, University of Missouri School of Law. B.S. 1991, Willamette University; J.D. 1996, University of Nebraska; Ph.D. (Psychology) 1998, University of Nebraska.

John M. Darley, Dorman T. Warren Professor of Psychology, Department of Psychology and Public Affairs, Woodrow Wilson School of Public and International Affairs, Princeton University. B.A. 1960, Swarthmore College; Ph.D. (Psychology) 1965, Harvard University.

Robert J. MacCoun, Professor of Public Policy and Law, Goldman School of Public Policy and Boalt Hall School of Law, University of California at Berkeley. B.A. 1980, Kalamazoo College; Ph.D. (Psychology) 1984, Michigan State University.

The authors would like to thank the participants at the Brooklyn Law School Symposium, "Responsibility and Blame: Psychological and Legal Perspectives," for their valuable comments and Jason Moore and Josie Pottebaum for their very helpful research assistance. 
In contrast to many traditional legal and economic portrayals of legal decision making which posit that decision makers can pursue single motives as instructed, Part I argues that jurors and other finders-of-fact deciding civil cases ought to be thought of as pursuing many different goals simultaneously. This Part briefly describes many of the goals that may underlie decision making in civil cases and introduces a set of basic goal management principles that define how these goals interrelate. Part II describes social psychological research that suggests that legal decision makers may be motivated to pursue a variety of goals in addition to the traditional goals of determining fault, compensating plaintiffs and deterring defendants. Different motives for distributing resources, value expressive goals and a need to restore the proper relative moral balance between the parties may all play a role in civil decision making. In Part III, we propose that decision makers may attempt simultaneously to satisfy these multiple goals through a process of parallel constraint satisfaction.

\section{DECISION MAKER GOALS}

\section{A. Traditional Legal and Economic Models of Decision Making}

Traditional descriptions of legal decision making presume, at least implicitly, that jurors and other legal factfinders are driven by a single motive at any given time and are able to focus on one purpose to the exclusion of others in making a given decision. Further, these descriptions assume that the single purpose on which decision makers will focus is the one that the legal system finds appropriate for making the judgment in question. Since the legal system regards different purposes as appropriate for the different decisions it asks decision makers to make about a single case, it assumes that the decision makers will rotate into place the decision rule that the justice system instructs them to use. The system assumes further that decision makers will apply that (and only that) decision rule for the decision in question. This view of system conforming, single rule governed factfinders underlies numerous legal rules that assume decision makers can compartmentalize information and make independent judgments. For example, decision makers are asked to isolate their reactions to extra-evidentiary information, such as 
pretrial publicity or inadmissible evidence, from their evaluation of the trial evidence. ' Similarly, decision makers are expected to use certain evidence for some purposes, but not for others. For example, decision makers may use prior record testimony to impeach a defendant's credibility as a witness but not to determine his or her culpability. ${ }^{2}$ Decision makers are also often asked to reach independent verdicts on multiple claims, for multiple plaintiffs or against multiple defendants in a single trial. ${ }^{3}$

Sometimes it is not the trial evidence that requires compartmentalization, but the rules or motives for the decision or set of decisions made. For instance, in civil trials decision makers are expected to compartmentalize their decisions so that liability, compensation and punitive damages judgments are each made independently. Decision makers are presumed to pursue different goals through each decision. Specifically, decision makers are expected to be driven by a motive of causal accuracy in making liability determinations, by the plaintifffocused motive of compensation in making compensatory damages determinations and by the defendant-focused motives of retribution and deterrence in making punitive damages determinations. ${ }^{4}$ In fact, it becomes more complicated. Given the different decision motives, decision makers are asked to use each decision to achieve separate objectives and may, therefore, be asked to consider certain evidence as relevant to only some

1 See generally Christina A. Studebaker \& Steven D. Penrod, Pretrial Publicity: The Media, the Law, and Common Sense, 3 Psychol. PuB. PoL'Y \& L. 428 (1997); Shari Seidman Diamond \& Neil Vidmar, Jury Room Ruminations on Forbidden Topics, 87 VA. L. REV. 1857, 1860 (2001) ("In both instances [pretrial publicity and legally irrelevant evidence], jurors are instructed to set aside (to erase) information that is already available to them and to reach their verdicts based simply on the legally permissible evidence which has been presented at trial. While courts recognize that jurors cannot be expected to proceed in this fashion on some occasions, granting a change of venue or a mistrial as a remedy, the reliance on simple admonitions to disregard inadmissible information reflects a perception of the jury as a blank slate on which trial testimony can be written and erased.").

${ }^{2}$ See FED. R. EVID. 404(b), 609.

${ }^{3}$ See FED. R. CIV. P. 13 (counterclaims and cross-claims); 14 (third-party practice); 18 (joinder of claims and remedies); 19 (joinder of persons needed for just adjudication); 20 (permissive joinder of parties); 21 (misjoinder and non-joinder of parties); 22 (interpleader); 23 (class actions); \& 24 (intervention).

4 With regard to punitive damages, the goal of deterrence has been the primary focus of many legal analysts. See, e.g., David Crump, Evidence, Economics, and Ethics: What Information Should Jurors be Given to Determine the Amount of a Punitive-Damage Award?, 57 MD. L. REV. 174 (1998); A. Mitchell Polinsky \& Steven Shavell, Punitive Damages: An Economic Analysis, 111 HARV. L. REv. 869 (1998). But see Marc Galanter \& David Luban, Poetic Justice: Punitive Damages and Legal Pluralism, 42 AM. U. L. REV. 1393 (1993). 
of these decisions but not to others. For example, defendant wealth is often appropriately considered as a factor in punitive damages decisions, but should not affect decisions about liability or compensatory damages. ${ }^{5}$ Similarly, decision makers may be asked to postpone certain judgments until others have been reached, and to prevent possible conclusions of the postponed judgments from influencing prior decisions. In civil trials, for instance, jurors' views regarding damages are not to influence their evaluation of defendant liability.

In a similar way, economic models of legal decision making also tend to presume that legal decision makers pursue unitary objectives. A clear example of this is the optimal deterrence model, where the primary purpose of a civil verdict, including any punitive damages award, is to set damages at the level that will result in the most efficient deterrence of harmful behavior. ${ }^{7}$ According to optimal deterrence theory, the

5 See Jennifer H. Arlen, Should Defendants' Wealth Matter?, 21 J. LEGAL STUD. 413 (1992); Keith N. Hylton, Punitive Damages and the Economic Theory of Penalties, 87 GEo. L.J. 421 (1998); Thomas Koenig \& Michael Rustad, "Crimtorts" as Corporate Just Deserts, 31 U. MICH. J.L. REFoRM 289, 315 (1998); Michael Rustad, In Defense of Punitive Damages in Products Liability: Testing Tort Anecdotes with Empirical Data, 78 Iowa L. Rev. 1 (1992). See also Pac. Mut. Life Ins. Co. v. Haslip, 499 U.S. 1, 6 n.1 (1991); TXO Prod. Corp. v. Alliance Res. Corp., 509 U.S. 443, 464 n.29 (1993); RESTATEMENT (SECOND) OF TORTS \& 908 (1979). Some state statues specifically note wealth as a factor: ALASKA STAT. $\$$ 09.17.020(c) (2002); CAL. CIV. CODE § 3295(d) (West 1997); KAN. STAT. ANN. § 60-3702(b)(6) (1994); MD. CODE ANN., CTS. \& JUD. Proc. § 10-913 (2002); MINN. STAT. ANN. § 549.20(3) (West 2000); Miss. CODE ANN. \& 11-1-65(1)(e) (1999); MO. ANN. STAT. \$ 510.263(2) (West 2003); MONT. CODE ANN. \& 271-221(7)(a) (1996); N.J. STAT. ANN. \& 2A:15-5.12 (2000); N.C. GEN. STAT. \& 1D-35 (2000); OHIO REv. CODE ANN. $\$ 2314.21$ (Anderson 2001); OKLA. STAT. ANN. tit. 23, $\$ 9.1$ (West 2001); 40 Pa. Cons. STAT. ANN. $\$ 1301.812$-A(a) (West 2001); Tex. Civ. PraC. \& ReM. CODE ANN. \$ 41.011 (2001); UTAH CODE ANN. § 78-18-1(2) (2000). But see Kenneth S. Abraham \& John C. Jeffries, Jr., Punitive Damages and the Rule of Law: The Role of Defendant's Wealth, 18 J. LEGAL STUD. 415 (1989); Crump, supra note 4; Polinsky \& Shavell, supra note 4. A few states prohibit the use of financial status information. See, e.g., COLO. REV. STAT. § 13-21-102(6) (1997); N.D. CenT. CODE § 32-03.2-11(3) (2001). For empirical studies examining the effects of wealth on decision making in civil cases see Valerie Hans, Business ON TRIal: The Civil JuRy and Corporate RESPONSIBILITY 112-37 (2000); Valerie P. Hans \& M. David Ermann, Responses to Corporate Versus Individual Wrongdoing, 13 LAW \& HUM. BEHAV. 151, 157 (1989); Robert J. MacCoun, Differential Treatment of Corporate Defendants by Juries: An Examination of the "Deep-Pockets" Hypothesis, 30 LAW \& SoC'Y REV. 121 (1996); Jennifer K. Robbennolt, Punitive Damages Decision Making: The Decisions of Citizens and Trial Court Judges, 26 LAW \& HUM. BEHAV. 315 (2002); NEIL VIDMAR, MEDICAL. MALPRACTICE AND THE AMERICAN JURY: CONFRONTING THE MYTHS ABOUT JURY INCOMPETENCE, DEEP POCKETS, AND OUTRAGEOUS DAMAGE AWARDS 203-20 (1995).

${ }^{6}$ Similarly, in criminal trials, jurors' views regarding sentence severity should not influence their evaluation of defendant guilt.

${ }^{7}$ Polinsky \& Shavell, supra note 4; W. Kip Viscusi, The Challenge of Punitive Damages Mathematics, 30 J. LEGAL STUD. 313, 331 (2001). The notion of "optimal" deterrence "implies deterring offensive conduct only up to the point at which 
purpose of punitive damages is to offset any deficit in the ability of compensatory damages to deter harmful behavior caused by any ability the defendant has to escape detection or liability. ${ }^{8}$ In accordance with this theory, the likelihood that the harmful conduct will be detected ought to be related to the appropriate degree of punishment. ${ }^{9}$ Under this model, decision makers are expected to render punitive damages decisions that vary inversely with the likelihood of detection; their decisions are considered to be erroneous if they do not. ${ }^{10}$ Even when these traditional legal and economic models are viewed as purely normative or prescriptive-rather than descriptive of actual decision making - their use as a baseline or benchmark for evaluating jury performance implicitly adopts the models' narrow goal conceptualization.

Much empirical research into legal decision making, however, demonstrates that decision makers have difficulty with the tasks these models require; the models assume that decision makers can select and exclusively use a single, legally appropriate decision rule. Decision makers have trouble, for example, ignoring pretrial publicity ${ }^{11}$ or inadmissible evidence, ${ }^{12}$ using specified evidence for some purposes but not

society begins to lose more from deterrence efforts than from the offenses it deters" in contrast to "complete" deterrence in which the goal is to "stopl offenders from committing offensive acts." Hylton, supra note 5, at 421.

${ }^{8}$ Polinsky \& Shavell, supra note 4 , at 873-74.

It follows from these observations that a crucial question for consideration is whether injurers sometimes escape liability for harms for which they are responsible. If they do, the level of liability imposed on them when they are found liable needs to exceed compensatory damages so that, on average, they will pay for the harm that they cause. This excess liability can be labeled "punitive damages," and failure to impose it would result in inadequate deterrence. In summary, punitive damages ordinarily should be awarded if, and only if, an injurer has a chance of escaping liability for the harm he Id. causes.

${ }^{9}$ Id. at 889-90.

${ }^{10}$ See generally Polinksy \& Shavell, supra note 4; Viscusi, supra note 7.

1 See Studebaker \& Penrod, supra note 1 (review); Brian H. Bornstein et al., Pretrial Publicity and Civil Cases: A Two Way Street?, 26 LAW \& HUM. BEHAV. 3 (2002) (examining the effects of pretrial publicity in civil cases); Nancy Mehrkens Steblay et al., The Effects of Pretrial Publicity on Juror Verdicts: A Meta-Analytic Review, 23 LAW \& HUM. BEHAV. 219 (1999) (meta-analysis). See generally Special Issue, Empirical and Legal Perspectives on the Impact of Pretrial Publicity, 26 LAW \& HUM. BEHAV. 1 (2002). See also Jennifer K. Robbennolt \& Christina A. Studebaker, News Media Reporting on Civil Litigation and Its Influence on Civil Justice Decision Making, 27 LAW \& HUM. BEHAV. 5 (2003) (reviewing empirical research on pretrial publicity effects in civil cases).

12 See Stephan Landsman \& Richard F. Rakos, A Preliminary Inquiry into the Effects of Potentially Biasing Information on Judges and Jurors in Civil Litigation, 
for others $;^{13}$ reaching independent verdicts on multiple claims, for multiple plaintiffs or against multiple defendants in a single trial $;{ }^{14}$ compartmentalizing liability, compensation and punishment decisions $;{ }^{15}$ and effecting optimal deterrence to the

12 BEHAV. SCI. \& L. 113 (1994) (finding that judges' and jurors' liability decisions and perceptions of the trial were similarly influenced by exposure to potentially biasing, but inadmissible, evidence).

${ }^{13}$ See Sarah Tanford \& Michele Cox, The Effects of Impeachment Evidence and Limiting Instructions on Individual and Group Decision Making, 12 LAW \& HUM. BEHAV. 477 (1988); Roselle L. Wissler \& Michael J. Saks, On the Inefficacy of Limiting Instructions: When Jurors Use Prior Conviction Evidence to Decide on Guilt, 9 LAW \& HUM. BEHAV. 37 (1985).

${ }^{14}$ For empirical studies of multiple decisions in civil trials see, e.g., Irwin A. Horowitz \& Kenneth S. Bordens, The Effects of Jury Size, Evidence Complexity, and Note Taking on Jury Process and Performance in a Civil Trial, 87 J. APPLIED PSYCHOL. 121 (2002) (multiple plaintiffs in civil trial); Irwin A. Horowitz \& Kenneth S. Bordens, The Consolidation of Plaintiffs: The Effects of Number of Plaintiffs on Jurors' Liability Decisions, Damage Awards, and Cognitive Processing of Evidence, 85 J. APPLIED PSYCHOL. 909 (2000) (civil trial-multiple plaintiffs); Kenneth S. Bordens \& Irwin A. Horowitz, The Limits of Sampling and Consolidation in Mass Tort Trials: Justice Improved or Justice Altered?, 22 LAW \& PSYCHOL. REV. 43 (1998). For empirical studies of the effects of joinder in criminal cases see Kenneth S. Bordens \& Irwin A. Horowitz, Prejudicial Joinder of Multiple Offenses: Relative Effects of Cognitive Processing and Criminal Schema, 7 BASIC \& APPLIED Soc. Psychol. 243 (1986); Sarah Tanford, Decision-Making Processes in Joined Criminal Trials, 12 CRIM. JUST. \& BEHAV. 367 (1985); Sarah Tanford \& Steven Penrod, Social Inference Processes in Juror Judgments of Multiple-Offense Trials, 47 J. PERSONALITY \& SOC. PsYchol. 749 (1984); Sarah Tanford \& Steven Penrod, Biases in Trials Involving Defendants Charged with Multiple Offenses, 12 J. APPLIED SOC. PSYCHOL. 453 (1982); Irwin A. Horowitz, et al., A Comparison of Verdicts Obtained in Severed and Joined Criminal Trials, $10 \mathrm{~J}$. APPLIED SOC. PSYCHOL. 444 (1980). See also review in Kenneth S. Bordens \& Irwin A. Horowitz, Joinder of Criminal Offenses: A Review of the Legal and Psychological Literature, 9 LAW \& HUM. BEHAV. 339 (1985).

${ }^{15}$ While some studies find that jurors and other legal decision makers are somewhat successful at compartmentalizing information in deciding civil cases, other studies demonstrate areas of difficulty. For empirical studies examining the possibility of leakage among the different decisions jurors must make in civil cases see Corrine Cather et al., Plaintiff Injury and Defendant Reprehensibility: Implications for Compensatory and Punitive Damage Awards, 20 LAW \& HUM. BEHAV. 189 (1996); Michelle Chernikoff Anderson \& Robert J. MacCoun, Goal Conflict in Juror Assessments of Compensatory and Punitive Damages, 23 LAW \& HuM. BeHAV. 313 (1999); Irwin A. Horowitz \& Kenneth S. Bordens, An Experimental Investigation of Procedural Issues in Complex Tort Trials, 14 LAW \& HUM. BEHAV. 269 (1990); MacCoun, supra note 5; Robbennolt, supra note 5; Jennifer K. Robbennolt \& Christina A. Studebaker, Anchoring in the Courtroom: The Effects of Caps on Punitive Damages, 23 LAW \& HuM. BEHAV. 353 (1999); Roselle L. Wissler et al., The Impact of Jury Instructions on the Fusion of Liability and Compensatory Damages, 25 LAW \& HUM. BEHAV. 125 (2001); Douglas J. Zickafoose \& Brian H. Bornstein, Double Discounting: The Effects of Comparative Negligence on Mock Juror Decision Making, 23 LAW \& HUM. BEHAV. 577 (1999). For empirical studies examining the effects of bifurcation in civil cases, see Stephan Landsman et al., Be Careful What You Wish For: The Paradoxical Effects of Bifurcating Claims for Punitive Damages, 1998 WISC. L. REV. 297; Edith Greene et al., Compensating Plaintiffs and Punishing Defendants: Is Bifurcation Necessary?, 24 LAW \& HUM. BEHAV. 187 (2000); Horowitz \& Bordens, supra; Robbennolt \& Studebaker, supra. See also Hans Zeisel \& Thomas Callahan, Split Trials and Time Saving: A Statistical Analysis, 76 HARv. L. REV. 1606 (1963). 
exclusion of other goals. ${ }^{16}$ In contrast to the legal and economic models that portray jurors and other finders-of-fact as singlemindedly pursuing individual, separable goals, we suggest that legal decision makers attempt to best use the available verdict options to satisfy numerous goals simultaneously.

\section{B. Decision Makers as Goal Managers}

Civil cases evoke multiple social and moral concerns, both normative and non-normative, that factor into legal decision making. For example, legal decision makers may attempt to reach a verdict that is consistent with the available evidence. ${ }^{17}$ They may attempt to achieve distributive justice by assessing liability proportionally with fault or by allocating resources to each party in proportion to that party's need. ${ }^{18}$ They may seek to compensate plaintiffs appropriately, avoiding overcompensation and undercompensation. They may endeavor to effect deterrence in some measure, exact retribution or restore an appropriate balance of justice between the parties. ${ }^{19}$ Just as the law more generally may serve an expressive function, ${ }^{20}$ so too may jurors attempt to express symbolic values through their verdicts. ${ }^{21}$ In addition, jurors may show reactance in the face of blatant manipulative tactics by counsel, attempt to comply with economic logic and attempt to reconcile conflicting (intrajuror and interjuror) interpretations of the judge's instructions. At the same time, they may desire to

${ }^{16}$ See Cass R. Sunstein et al., Do People Want Optimal Deterrence?, 29 J. LEGAL STUD. 237 (2000).

${ }^{17}$ See Nancy Pennington \& Reid Hastie, The Story Model for Juror Decision Making, in INSIDE THE JUROR: THE PSYCHOLOGY OF JUROR DECISION MAKING 192 (Reid Hastie ed., 1993). For additional discussion of the story model of juror decision making see infra Part III.B.

${ }^{18}$ See Morton Deutsch, Equity, Equality, and Need: What Determines Which Value Will be Used as the Basis of Distributive Justice, 31 J. Soc. IsSUES 137 (1975). See also infra Part II.A.

${ }_{19}$ See Edith Greene et al., The Effects of Limiting Punitive Damage Awards, 25 LAW \& HUM. BEHAV. 217, 229 (2001) (discussing mock jurors endorsement of compensation, deterrence and punishment intentions); Reid Hastie et al., Juror Judgments in Civil Cases: Effects of Plaintiff's Requests and Plaintiff's Identity on Punitive Damage Awards, 23 LAW \& HuM. BEHAV. 445, 462 (1999) (same). See also Kevin M. Carlsmith et al., Why Do We Punish? Deterrence and Just Deserts as Motives for Punishment, 83 J. PERSONALITY \& SOC. PSYCHOL. 284 (2002) (examining different punishment goals in criminal decision making); John M. Darley et al., Incapacitation and Just Deserts as Motives for Punishment, 24 LAW \& HUM. BEHAV. 659 (2000) (same).

${ }^{20}$ See generally Cass R. Sunstein, On the Expressive Function of Law, 144 U. PA. L. REV. 2021 (1996).

${ }^{21}$ See infra Parts II.B and II.C. 
"finish the trial and go home; avoid fighting with other jurors; [and] avoid the wrath of the defendant, plaintiff, or community." While decision makers in civil cases may struggle to satisfy this assortment of goals, the legal decision making task affords only limited mechanisms through which to do so-primarily, a liability verdict, compensatory damages and, sometimes, punitive damages.

The array of possible goals and the avenues available to accomplish them are interrelated in complex ways. We propose four basic goal management principles that describe the interrelated nature of these goals and actions. First, the principle of equifinality holds that some goals may be alternately satisfied through multiple pathways. Decision makers, for example, can compensate the plaintiff most straightforwardly through a compensatory damage award, but can also award punitive damages to achieve this goal. ${ }^{23}$ Second, the principle of best fit holds that pathways may sometimes fulfill some goals better than others. For example, compensatory damages may serve compensatory goals better than they do retributive goals. Third, the principle of multifinality holds that a particular pathway may accomplish multiple goals simultaneously. Some of the decision makers' objectives may be consistent with each other and may be achieved concurrently. Requiring a defendant to pay money to a plaintiff, for example, may serve to compensate the plaintiff, to educate the defendant and others about socially acceptable conduct and also to punish the defendant. ${ }^{24}$ Similarly, a punitive damage award may fulfill goals of punishment and deterrence. Finally, the principle of goal incompatibility holds that some objectives will inevitably conflict and, thus, be difficult or impossible to satisfy concurrently. For instance, a particular punitive damages award may be thought to punish appropriately the defendant, but to overcompensate the

${ }^{22}$ Anderson \& MacCoun, supra note 15, at 315 (internal citations omitted).

${ }^{23}$ Arie W. Kruglanski et al., A Theory of Goal Systems, 34 ADVANCES EXPERIMENTAL SOC. PSYCHOL. 331, 334 (2002) (describing principle of equifinality). See Anderson \& MacCoun, supra note 15, at 315 ("We suggest that jurors manage goal conflict through a principle of equifinality. By equifinality, we mean that actors can pursue goals through multiple pathways; if one pathway is thwarted, another is used.") (internal citations omitted).

${ }^{24}$ Kruglanski et al., supra note 23 , at 334 (describing principle of multifinality). 
plaintiff. The challenge for jurors and other legal factfinders is to reach a verdict that best reconciles these different goals. ${ }^{25}$

\section{COMPETING GOALS}

In addition to the traditional goals of the civil justice system of determining liability, compensating plaintiffs and deterring defendants, we suggest that there are numerous other goals that play a role in deciding cases. When assessing compensatory damages, for example, legal decision makers may consider the relative needs of the parties rather than solely attempting to reach outcomes that are proportionate to fault. Moreover, decision makers may use their decisions as much to "make statements" and endorse or reinforce community values as to influence behavior directly. Thus, in trying to understand decision making in civil cases, expressive goals are an important consideration. In addition, legal decision makers may be concerned not just with a commodified conception of compensation, but also with restoring the moral balance between the parties to the lawsuit.

\section{A. Distributive Justice}

Models of distributive justice attempt to explain how people determine whether an outcome is fair. In general, the law is intended to follow a model of distributive justice based on allocation of fault such that a person is considered blameworthy when she engages in conduct that causes intended harm or involves an undue risk of harm. ${ }^{26}$ Under a model of distributive justice based on fault, the losses resulting from an injury-producing incident are allocated to each party in proportion to that party's fault. A pure comparative negligence standard can be thought of as following a proportionality model. $^{27}$

Psychologically, however, it is plausible that in attempting to realize distributive justice among the parties, decision makers may be motivated not only by a desire to achieve an allocation of loss proportionate to fault, but also by

${ }^{25}$ In Part III, we describe a constraint satisfaction perspective that might be deployed to formalize these principles.

${ }^{26}$ W. Page Keeton et al., Prosser and KeEton ON THE LaW OF TORTS (5th ed. 1984) (describing the fault principle).

${ }^{27}$ But see Zickafoose \& Bornstein, supra note 15 (finding that jurors have difficulty implementing a pure comparative negligence standard). 
a desire to allocate resources among the parties equally or in proportion to each party's need.$^{28}$ Empirical data suggest that both motives may come into play when jurors are asked to decide civil cases. Consistent with the traditional doctrine and a norm of equity, Robert MacCoun found that jury pool members, who were asked to decide a fictitious civil lawsuit, strongly endorsed the notion that verdicts should be based on fault, such that the agent at fault should bear the cost of the injuries. ${ }^{29}$ At the same time, however, MacCoun also found that, second to achieving fault-proportionality, the next most commonly endorsed goal of mock jurors was to help needy plaintiffs obtain compensation. ${ }^{30}$ This goal is consistent with a norm of distributive justice based on need. Thus, jurors may hold a defendant responsible in order to compensate the plaintiff for her loss. Supporting this notion, a number of empirical studies have found a relationship between injury severity and civil liability, such that defendants are more likely to be found liable for plaintiffs' injuries when those injuries are more severe. ${ }^{3 t}$

Each of these motives-equity, equality and needamong others, may simultaneously exert influence on decision makers attempting to make appropriate determinations in civil cases. While one or another of these norms may predominate in a given case or for a given decision within a case, other cases or decisions may implicate several of the norms at the same time. ${ }^{32}$ Accordingly, decision makers must attempt to balance the competing concerns of the different distributive justice principles in order to satisfy concurrently their competing goals.

${ }^{28}$ See Deutsch, supra note 18.

${ }^{29}$ MacCoun, supra note 5, at 133.

${ }^{30} \mathrm{Id}$.

${ }^{31}$ See, e.g., Brian H. Bornstein, From Compassion to Compensation: The Effect of Injury Severity on Mock Jurors' Liability Judgments, 28 J. APPLIED SOC. PSYCHOL. 1477 (1998); Troyen A. Brennan et al., Relation Between Negligent Adverse Events and the Outcomes of Medical-Malpractice Litigation, 335 NEW ENG. J. MED. 1963 (1996). But see Edward Green, The Reasonable Man: Legal Fiction or Psychosocial Reality?, 2 LAW \& Soc'y REV. 241 (1967); MARK A. PETERSON, COMPENSATION OF INJURIES: CIVIL JURY VERDICTS IN COOK COUNTY (1984). See review in Jennifer K. Robbennolt, Outcome Severity and Judgments of "Responsibility": A Meta-Analytic Review, 30 J. APPLIED SOC. PSYCHOL. 2575 (2000) (finding a statistically significant, but small association).

${ }^{32}$ See Deutsch, supra note 18, at 143-47 (discussing the conditions under which each norm is likely to emerge). 


\section{B. Value Expression}

Another class of goals that may influence legal decisions is related to the expressive functions such decisions can serve. The law functions expressively to the extent that its role is more symbolic than instrumental, as it focuses on "making statements' as opposed to controlling behavior directly. "

Similarly, civil factfinders who hold a defendant liable for a civil wrong and require that defendant to compensate the plaintiff for her injuries make statements about socially acceptable and unacceptable behavior as well as the appropriate relationship between the parties. In particular, punishment, including civil punishment, is said to serve, in part, the symbolic function of expressing "moral condemnation," ${ }^{34}$ "attitudes of resentment and indignation, and . . . judgments of disapproval and reprobation., ${ }^{35}$ As Joel Feinberg says of punitive damages: "What more dramatic way of vindicating his violated right can be imagined than to have a court thus forcibly condemn its violation through the symbolic machinery of punishment? ${ }^{\text {"36 }}$ Although deterrence theories can accommodate such expressions by interpreting them post hoc as threats or incentives, we believe that a rational choice perspective fails to capture the complexity and emotional resonance of these more symbolic messages. The following discussion of attitude functions, sacred value protections, taboo trade-offs and incommensurability highlights this complexity.

\section{Attitude Functions}

The functional attitude tradition in social psychology suggests that attitude expressions may serve a variety of functions and may even serve more than one function or goal simultaneously. Importantly, in addition to holding and

${ }^{33}$ Sunstein, supra note 20, at 2024.

34 Dan M. Kahan, Punishment Incommensurability, 1 BUFF. CRIM. L. REV. 691, 696 (1998) ("Since condemning is central to what society is trying to accomplish when it punishes, substituting a form of affliction that doesn't convey that meaning for one that does is expressively irrational."); Dan M. Kahan, What Do Alternative Sanctions Mean?, 63 U. CHI. L. REV. 591 (1996).

${ }^{35}$ Joel Feinberg, The Expressive Function of Punishment, in DOING AND Deserving 95, 98 (1970) ("Punishment, in short, has a symbolic significance largely missing from other kinds of penalties."). Jean Hampton, An Expressive Theory of Retribution, in RETRIBUTIVISM \& ITS CRITICS (Wesley Cragg ed., 1992) (discussing the expressive function of punishment generally).

${ }^{36}$ Feinberg, supra note 35, at 104. 
expressing attitudes on utilitarian or instrumental grounds such as structuring knowledge or as a result of the rewards or punishments associated with the object of the attitude, people may also hold and express attitudes for symbolic or expressive reasons. ${ }^{37}$ Attitudes serve value-expressive functions when they are "based on needs to define oneself by expressing important values and aligning oneself with important reference groups. ${ }^{, 38}$

A particular attitude may function primarily to fulfill instrumental or expressive goals, to fulfill both types of goals simultaneously (a "complex attitude"), or to fulfill neither instrumental nor expressive goals (a "nonfunctional attitude"). ${ }^{39}$ Features of the individual holding the attitude, of the attitude object and of the situation calling for an attitude expression may all interact to determine whether a particular function or functions is elicited. ${ }^{40}$ Consistent with this functional understanding of attitudes, Gregory Herek and John Capitanio found, for example, that attitudes toward people with AIDS are motivated both by evaluative concerns (personal apprehension about contracting HIV) and expressive concerns (conveying political or religious values), with expressive

${ }^{37}$ See generally Alice H. EAGLy \& Shelly Chaiken, The Psychology of AtTitudes 479-90 (Dawn Youngblood ed., 1993); Why We Evaluate: FunCTIONS of ATTITUDES (Gregory R. Maio \& James M. Olson eds., 2000); Gregory M. Herek, Can Functions be Measured? A New Perspective on the Functional Approach to Attitudes, 50 SOC. PSYCHOL. Q. 285 (1987) (describing methods for studying attitude functions) [hereinafter Functional Approach]; Gregory M. Herek, The Instrumentality of Attitudes: Toward a Neofunctional Theory, 42 J. Soc. Issues 99 (1986) [hereinafter Neofunctional Theory]. For related work on symbolic politics, see David O. Sears \& C.L. Funk, The Role of Self-Interest in Social and Political Attitudes, 24 ADVANCES EXPERIMENTAL SOC. PSYCHOL. 1 (1991); David O. Sears et al., Self-Interest vs. Symbolic Politics in Policy Attitudes and Presidential Voting, 74 AM. POL. SCI. REv. 670 (1980). In a similar way, the Heuristic-Systematic Model of persuasion proposes that systematic processing of attitude-relevant information is motivated not only by an instrumental concern for accuracy (i.e., "achieving valid attitudes that square with relevant facts"), but also by expressive concerns such as defense motivation (i.e., "the desire to form or to defend particular attitudinal positions") and impression motivation (i.e., "the desire to express attitudes that are socially acceptable"). See EAGLY \& CHAIKEN, supra, at 339-40; Roger Giner-Sorolla \& Shelly Chaiken, Selective Use of Heuristic and Systematic Processing Under Defense Motivation, 23 PERSONALITY \& SOC. PSYCHOL. BULL. 84 (1997) (testing defense motivations); Serena Chen et al., Getting at the Truth or Getting Along: Accuracy-Versus Impression-Motivated Heuristic and Systematic Processing, 71 J. PERSONALITY \& SOC. PSYCHOL. 262 (1996) (contrasting the processing and expressions of accuracy- and impression-motivated participants).

${ }^{38}$ Herek, Neofunctional Theory, supra note 37, at 106 . Herek also identifies two other expressive functions: social-expressive (based on needs for acceptance) and defensive (based on needs to reduce anxiety). $I d$.

${ }^{39}$ Id. at 106-07.

${ }^{40}$ Herek, Functional Approach, supra note 37, at 299-301. 
concerns predominating. ${ }^{41}$ Similarly, both value-expressive symbolic considerations and instrumental concerns for controlling behavior have been shown to underlie support for capital punishment, though there is evidence that symbolic concerns predominate. ${ }^{42}$

\section{Sacred Value Protection}

Philip Tetlock has recently proposed a model of behavior that suggests that, in addition to other goals, people may attempt to symbolically affirm core values that they believe have been threatened. ${ }^{43}$ Specifically, people will act to defend those "sacred values" that are "implicitly or explicitly treat[ed] as possessing infinite or transcendental significance that precludes comparisons, trade-offs, or indeed any other mingling with bounded or secular values." ${ }^{44}$ In his "sacred value protection model," Tetlock provides evidence that, in the face of a perceived threat to one of these central beliefs, people will endeavor to "protect their private selves and public identities from moral contamination by impure thoughts and deeds. ${ }^{\$ 45}$

The sacred value protection model posits that witnessing incursions onto sacred values triggers responses that attempt to re-affirm those values. First, the model posits

${ }^{41}$ Gregory M. Herek \& John P. Capitanio, Symbolic Prejudice or Fear of Infection? A Functional Analysis of AIDS-Related Stigma Among Heterosexual Adults, 20 BASIC \& APPLIED SOC. PSYCHOL. 230, 236 (1998).

${ }^{42}$ See Tom R. Tyler \& Renee Weber, Support for the Death Penalty: Instrumental Response to Crime, or Symbolic Attitude?, 17 LAW \& SOC'Y REV. 21 (1982). See also Phoebe C. Ellsworth \& Samuel R. Gross, Hardening of the Attitudes: Americans' Views on the Death Penalty, 50 J. Soc. ISSUES 19 (1994).

${ }^{43}$ Philip E. Tetlock et al., The Psychology of the Unthinkable: Taboo Trade Offs, Forbidden Base Rates, and Heretical Counterfactuals, 78 J. PERSONALITY \& SOC. PSYCHOL. 853 (2000); Philip E. Tetlock, Social Functionalist Frameworks for Judgment and Choice: Intuitive Politicians, Theologians, and Prosecutors, 109 PSYCHOL. REV. 451 (2002).

44 Tetlock et al., supra note 43 , at 853 . See also Tetlock, supra note 43 , at 454 (stating that sacred values are "values that-by community consensus-are deemed beyond quantification or fungibility").

${ }^{45}$ Tetlock et al., supra note 43 , at 853 (portraying people as "struggling to protect sacred values from secular encroachments by increasingly powerful societal trends toward market capitalism (and the attendant pressure to render everything fungible) and scientific naturalism (and the attendant pressure to pursue inquiry wherever it logically leads)"); Tetlock, supra note 43, at 458 (“[T]he principled defense of the sacred from encroachments by powerful societal trends toward science, technology, and the calculus of capitalism (and attendant pressures to pursue inquiry wherever it leads and to translate all values into a utility or monetary metric)."). In this way, Tetlock suggests that people operate as intuitive theologians (as compared to intuitive scientists, economists, politicians or prosecutors). Tetlock et al., supra note 43, at 853-54. 
that people will respond with moral outrage when core values are threatened. ${ }^{46}$ Moral outrage has been shown to manifest itself in negative evaluations of, and negative emotional responses, such as anger, toward individuals who have intruded on closely held values. Moral outrage also leads to greater support for the punishment of those who have threatened these moral norms. ${ }^{47}$ This connection between feelings of moral outrage and punitiveness is also supported by research on the psychology of punitive damages awards, which has demonstrated that jurors' feelings of moral outrage about a defendant's conduct predict the degree to which they believe that the defendant ought to be punished. ${ }^{48}$

Second, the model predicts that threats to sacred values will elicit expressions of moral cleansing that are designed to distance the witness from the offense and to buttress the threatened principles. ${ }^{49}$ In this way, the witness affirms the closely held value and upholds his or her connection to the moral community ${ }^{50}$ For example, people who observe a decision that threatens a sacred value, such as the selling of bodily organs to the highest bidder, are more likely to volunteer for a campaign to promote organ donation than are those who do not observe such a decision. ${ }^{51}$ This behavior serves to distance them from the offensive trade-off and affirms the threatened sacred value.

\section{Taboo Trade-Offs and Incommensurability}

One type of threat to sacred values occurs when decision makers entertain what are considered to be illegitimate comparisons between entities and values that defy comparison. In their theory of "taboo trade-offs," Alan Page Fiske and Philip

${ }^{46}$ Tetlock et al., supra note 43 , at 855 .

${ }^{47}$ Alan Page Fiske \& Philip E. Tetlock, Taboo Trade-Offs: Reactions to Transactions that Transgress the Spheres of Justice, 18 POL. PSYCHOL. 255, 285-86 (1997). For empirical evidence that taboo trade-offs elicit greater outrage see Tetlock et al., supra note 43, at 857-59; Philip E. Tetlock et al., Revising the Value Pluralism Model: Incorporating Social Content and Context Postulates, in THE PSYCHOLOGY OF VALUES: THE ONTARIO SYMPOSIUM 25 (Clive Seligman et al. eds., 1996).

${ }^{48}$ See Daniel Kahneman et al., Shared Outrage and Erratic Awards: The Psychology of Punitive Damages, 16 J. RISK \& UNCERTAINTY 49, 62 (1998); Cass R. Sunstein et al., Assessing Punitive Damages (with Notes on Cognition and Valuation in the Law), 107 YALE L.J. 2071 (1998).

\footnotetext{
${ }^{49}$ Tetlock et al., supra note 43 , at 853-54.

${ }^{50} \mathrm{Id}$. at 855 .

${ }^{51} I d$. at $858-59$.
} 
Tetlock brought together Fiske's theory of relational models ${ }^{52}$ and Tetlock's work on the psychology of value trade-offs ${ }^{53}$ to explain when trade-offs will be viewed as illegitimate (or taboo). ${ }^{54}$ Fiske posited four fundamental models that individuals in society use to structure their social relations. First, in relations governed by communal sharing, we classify individuals into groups and treat members of a class identically. ${ }^{55}$ Second, authority ranking is a relational model in which we treat individuals by their rank within the hierarchy of a group. ${ }^{56}$ Third, in relations governed by equality matching, we keep track of contributions and outcomes and attempt to keep them in balance. ${ }^{57}$ Finally, relations governed by market pricing operate in terms of exchange, as we value factors on an absolute metric and make trade-offs among them. ${ }^{58}$ Each relational model operates to appropriately govern different consensually agreed upon spheres of the social community. Moreover, different relational operations, modes of conduct and norms of distributive justice are appropriate within relationships governed by different relational models. ${ }^{59}$

A taboo trade-off occurs when there is a comparison or exchange between relationships that are treated as appropriately falling into different relational domains. This is particularly the case when a relationship appropriately treated with market pricing is compared or exchanged with relationships normally falling into one of the alternative relational models: communal sharing, authority ranking or equality matching. Especially proscribed are those trade-offs that 'treat 'sacred values' like honor, love, justice, and life as fungible." ${ }^{60}$ Thus, exchanges of money for things such as votes,

${ }^{52}$ Alan Page Fiske, The Four Elementary Forms of Sociality: Framework for a Unified Theory of Social Relations, 99 PSYCHOL. REV. 689 (1992).

${ }^{53}$ See Philip E. Tetlock, A Value Pluralism Model of Ideological Reasoning, 50 J. PERSONALITY \& SOC. PSYCHOL. 819 (1986); Tetlock et al., supra note 43.

${ }^{54}$ Fiske \& Tetlock, supra note 47.

${ }^{55}$ Fiske, supra note 52, at 690-91.

${ }^{56} I d$. at 691 .

${ }^{57} I d$.

${ }^{58} I d$. at $691-92$.

${ }^{59}$ See id. at 693-708; Robert J. MacCoun, The Costs and Benefits of Letting Juries Punish Corporations: Comment on Viscusi, 52 STAN. L. REV. 1821 (2000).

${ }^{60}$ Tetlock et al., supra note 43, at 854; Fiske \& Tetlock, supra note 47, at 256 ("By a taboo trade-off, we mean any explicit mental comparison or social transaction that violates deeply-held normative intuitions about the integrity, even sanctity, of certain forms of relationship and of the moral-political values that derive from those relationships."). 
babies, loyalty or love strike most people as distasteful and morally offensive. ${ }^{61}$

Such negative reactions are likely due, in part, to the cognitive difficulty that individuals have with comparing and making trade-offs between incommensurable entities. ${ }^{62}$ The lack of a common metric for evaluating things such as money and love make any comparison and attempt to make trade-offs cognitively challenging. However, Fiske and Tetlock suggest that this "resistance also runs deeper: there are moral limits to fungibility. People reject certain comparisons because they feel that seriously considering the relevant trade-offs would undercut their self-images and social identities as moral beings. "63 Fiske and Tetlock invoke the concept of "constitutive commensurability" to describe instances in which "entering one value into a trade-off calculus with the other subverts or undermines that value. This means that our relationships with each other preclude certain comparisons among values.", ${ }^{, 64}$ In these cases, it is not merely that the trade-off is cognitively complex or that we think that a proper quantitative valuation has not been achieved monetarily, i.e., that not enough money has been paid for the baby or the organ. Rather, the difficulty comes from a belief that to value some things in monetary terms is qualitatively incorrect; such comparisons invoke the wrong relational template and, accordingly, the valuation is of the wrong type. ${ }^{65}$

${ }^{61}$ Tetlock et al., supra note 43 , at 854 ("To transgress this boundary, to attach a monetary value to one's friendships, children, or loyalty to one's country, is to disqualify oneself from the accompanying social roles."); Fiske \& Tetlock, supra note 47, at 292 ("People probably cannot make reliable, meaningful comparisons across relational models, and they experience deep unease when asked to do so.").

${ }^{62}$ For discussions of incommensurability in law generally, see Margaret Jane Radin, Compensation and Commensurability, 43 DUKE L.J. 56 (1993); Cass R. Sunstein, Incommensurability and Valuation in Law, 92 MICH. L. REV. 779 (1994).

${ }^{63}$ Fiske \& Tetlock, supra note 47, at 256.

${ }^{64}$ Id. See also Sunstein, supra note 62 , at 796 ("Incommensurability occurs when the relevant goods cannot be aligned along a single metric without doing violence to our considered judgments about how these goods are best characterized.") (emphasis omitted); Kahan, Punishment Incommensurability, supra note 34 , at 695 ("[S]ignification of respect cannot be reproduced by any amount of money; even to attempt the substitution conveys that he does not value his colleague in the way appropriate to their relationship.").

${ }^{65}$ Sunstein, supra note 62 , at 788 ("We should distinguish between cases in which a monetary offer is entirely inappropriate . . . and cases in which the monetary sum, while appropriately offered, does not reflect a full or fully accurate valuation of the item in question."); id. at 795 ("But perhaps the resistance [to comparisons between money and risk to life or health] rests on a claim about appropriate kinds, not levels, of valuation."). Resource theory also suggests that different resource classes (love, status, information, money, goods and services) are not equally substitutable. See, e.g., 
As with other threats to sacred values, taboo trade-offs engender feelings of anger and outrage, negative attributions about those entertaining such comparisons, a desire to punish such offenders and a need to engage in moral cleansing. ${ }^{66}$ Punishment is central to symbolically restoring sacred values:

[O]nly reassurance that the wrong-doer has indeed been punished by the collective (whose norms have been violated) should be sufficient to restore the moral status quo ante and to reduce whatever cognitive and emotional unease was produced in individual observers by the original trade-off transgression. Indeed, punishments are forceful impositions of the relational models themselves, reestablishing their validity and hegemony. ${ }^{67}$

Accordingly, we might expect civil decision makers to react negatively to, and to express their discomfort punitively against, defendants who have made or entertained taboo tradeoffs. $^{68}$

\section{Resistance to Cost-Benefit Analysis}

Legal scholars have also noted this deeper reaction to taboo trade-offs. Cass Sunstein writes that

many people find it jarring to hear that, in light of actual occupational choices, a worker values his life at (say) eight million dollars, or that the protection of a life is "worth" eight million dollars. These claims are jarring not because we believe infinite social resources should be devoted to occupational safety. The claims are jarring because of the widespread perception that a life is not instrumental to some aggregate social goal, but worthy in itself-a belief in tension with applying the language of prices to human life. This is a plausible concern even if one ultimately concludes that (say) an eight million dollar expenditure is fully appropriate in cases of lives at risk. Certainly intrinsic goods do not have infinite value for purposes of law and policy. But even though they do not, the fact

Gregory V. Donnenwerth \& Uriel G. Foa, Effect of Resource Class on Retaliation to Injustice in Interpersonal Exchange, 29 J. PERSONALITY \& SOC. PSYCHOL. 785 (1974); J.L. Turner, Edna B. Foa \& Uriel G. Foa, Interpersonal Reinforcers: Classification, Interrelationship and Some Differential Properties, 19 J. PERSONALITY \& SOC. PSYCHOL. 168 (1971).

${ }^{66}$ Fiske \& Tetlock, supra note 47, at 285 (moral outrage).

Indeed, people tend to deny the necessity for many trade-offs, and are often distressed, angry, or confused when faced with the finds of explicit trade-offs we have been discussing. People commonly censure those who make such trade-offs explicit because they regard such trade-offs as transgressions indicative of aberrant, antisocial motives that threaten the social order.

Id. at 282. See supra notes 46-51 and accompanying text.

${ }^{67}$ Fiske \& Tetlock, supra note 47, at 286.

${ }^{68}$ See MacCoun, supra note 59. 
that we find it jarring to hear that a life is "worth" a specified amount of money is socially desirable, and not a product of simple confusion. ${ }^{69}$

Consistent with this observation and the theory of taboo trade-offs, recent empirical evidence suggests that civil jurors may be more punitive against companies that undertake costbenefit analyses in making safety decisions than they are against those who do not. W. Kip Viscusi examined the effect of corporate cost-benefit analyses on mock jurors using a scenario in which a defendant automobile company manufactured a line of cars with a defective electrical system which led to a specified number of burn deaths per year. ${ }^{70}$ The study used two versions of the case; in one version, the company used a costbenefit analysis to decide that it should not change the defective design to prevent this risk. ${ }^{71}$ Jurors appeared to react negatively to evidence that the company had conducted a costbenefit analysis. Viscusi found that jurors were more likely to award punitive damages and made marginally larger punitive damage awards when the company conducted a cost-benefit analysis. $^{72}$

These findings, though preliminary, ${ }^{73}$ are consistent with common intuitions about the effects of corporate costbenefit analysis on jurors. ${ }^{74}$ The theory of taboo trade-offs provides a psychologically sophisticated explanation for these findings and suggests that symbolic motives may have an influence on legal judgments. It is possible that by punishing

69 Sunstein, supra note 62 , at 804 .

${ }^{70}$ W. Kip Viscusi, Corporate Risk Analysis: A Reckless Act?, 52 STAN. L. REV. $547(2000)$.

${ }^{7} I d$.

${ }^{72} I d$.

${ }^{73}$ Additional research is needed to disentangle the multiple conditions in Viscusi's study and to explore the boundary conditions on any effects. See, e.g., Kevin M. O'Neil et al., Companies' Risky Decisions: Jurors Reactions to Cost-Benefit Analyses (March 8, 2002) (unpublished paper presented at American Psychology-Law Society Biennial Meeting, Austin, TX).

${ }^{4}$ Steven Garber, Product Liability, Punitive Damages, Business Decisions and Economic Outcomes, 1998 WIS. L. REv. 237, 287 n.135 ("It seems widely agreed by both plaintiffs' and defense attorneys that credible trial evidence of cost-benefit balancing-so-called 'trading off lives against dollars'-makes punitive damages particularly likely. This is in stark contrast to the fact that economic efficiency-and deterrence aimed at economic efficiency-requires cost-benefit balancing."). See also Mark Dowie, Pinto Madness, MOTHER JonES, Sept.-Oct. 1977, at 18 (describing the controversy over the revelation that the Ford Motor Company relied on a cost-benefit analysis in deciding against an eleven dollar safety alteration in each Ford Pinto, despite their anticipation that this could prevent almost two hundred burn deaths). 
the corporation through a punitive damage award, the mock jurors were attempting to distance themselves morally from the proscribed trade-off and symbolically reaffirm the value that they and their moral community place on life and safety. ${ }^{75}$

\section{Restoring Moral Balance}

\section{Valuing the Victim}

In similar ways, legal decision makers may also attempt to express support for the value of the victim of the wrongdoing through their verdicts. Philosopher Jean Hampton has developed an expressive theory of retribution based on the messages that wrongful behavior and sanctions send about the relative worth of the parties. ${ }^{76}$ Hampton posits that

[a] person behaves wrongfully in a way that effects a moral injury to another when she treats that person in a way that is precluded by that person's value, and/or by representing him as worth far less than his actual value; or in other words, when the meaning of her action is such that she diminishes him, and by doing so, represents herself as elevated with respect to him, thereby according herself a value that she does not have. ${ }^{77}$

When a wrongdoer engages in behavior that does not appropriately respect the value of another person, it "sends a false message about the value of the victim relative to the [wrongdoer]." " Such an action symbolically "demonstrates that she believes the worth of the victim makes such treatment permissible. ${ }^{n 9}$

To illustrate the message about the victim's worth sent by a wrongful act, Hampton uses the example of an asbestos

${ }^{75}$ See MacCoun, supra note 59.

${ }^{76}$ See Jean Hampton, Correcting Harms Versus Righting Wrongs: The Goal of Retribution, 39 UCLA L. REV. 1659, 1677 (1992).

${ }^{77}$ Id.; Hampton, supra note 35; Jean Hampton, The Retributive Idea, in FORGIVENESS AND MERCY, supra note 77, at 111.

${ }^{78}$ Hampton, supra note 35 , at 5 . See also Hampton, supra note 76 , at 1678 ("[H]arms anger us not merely because they cause suffering we have to see in others, but also because we see their inflictions as violative of the victim's entitlements given her value.").

${ }^{79}$ Hampton, supra note 35 , at 8. See also Hampton, supra note 77, at 44 ("When someone wrongs another, she does not regard her victim as the sort of person who is valuable enough to require better treatment."). See also Jeffrie Murphy, Forgiveness and Resentment, in FORGIVENESS AND MERCY, supra note 77, at 14, 25 ("[S] uch injuries are also messages-symbolic communications. They are ways a wrongdoer has of saying to us, 'I count but you do not,' 'I can use you for my purposes,' or 'I am here up high and you are there down below."). 
plant, where managers know the health risks, but fail to warn and protect their employees.

Their actions demonstrate how important the company's profits are to these managers: in virtue of their importance, they regard it as permissible to allow the employees to assume these risks to their health, rather than pay the costs necessary to do something to lower the risks and thereby lower profits. Those who commit such crimes essentially reason: "Nothing personal, but I've got to harm you in these ways given my interests-which are so important that you can be used or damaged to serve them." Such reasoning explains why these people inflict treatment upon others which is disrespectful of their value as persons. ${ }^{80}$

Similarly, Marc Galanter and David Luban argue that "culpably harming another person or being culpably negligent expresses a false view of the wrongdoer's value relative to that of the victim. . . . 'I can be negligent in marketing Dalkon Shields because you, the customer, do not matter very much."

Hampton argues that civil punishment is a way of attempting to reestablish the value of equality; that is to "remake the world in a way that denies what the wrongdoer's events have attempted to establish, thereby lowering the wrongdoer, elevating the victim, and annulling the act of diminishment. ${ }^{82}$ Because the message sent by the wrongful act "threatens to reinforce belief in the wrong theory of value by the community," ${ }^{83}$ punishment is sought that "symbolizes the correct relative value of wrongdoer and victim." Luban characterize this purpose for punishment as inflicting an "expressive defeat" on the wrongdoer. ${ }^{86}$

This philosophical account of retribution is consistent with the social psychological account provided by equity theory.

${ }^{80}$ Hampton, supra note 35 , at 8.

${ }^{81}$ Galanter \& Luban, supra note 4 , at 1432.

${ }^{82}$ Hampton, supra note 76, at 1686-87. See also Hampton, supra note 35, at 12 ("a way of denying a false message about worth, and thus a way of vindicating the worth of those who have been victims of wrongdoing").

B33 Hampton, supra note 76 , at 1678

${ }^{84}$ Hampton, supra note 77 , at 125 . See also Hampton, supra note 35 , at 13 (“[J]ust as the crime has symbolic meaning, so too does the punishment. . . . the punishment 'takes back' the demeaning message. . . . the evidence of value loss provided by the crime is nullified by the new evidence provided by the subordination effected through the punishment."); Hampton, supra note 76 , at 1686 ("[R]etribution is a response to a wrong that is intended to vindicate the value of the victim denied by the wrongdoer's action through the construction of an event that not only repudiates the action's message of superiority over the victim but does so in a way that confirms them as equal by virtue of their humanity.").

${ }^{85}$ Galanter \& Luban, supra note 4, at 1432. 
According to equity theorists, a wrongdoer's transgression against an injured party results in an inequity in their relationship; that is, the wrong creates a moral imbalance between the parties. ${ }^{86}$ Moreover, equity theory posits that "when individuals find themselves participating in inequitable relationships, they become distressed. The more inequitable the relationship, the more distress individuals feel. ${ }^{\$ 87}$ Upon discovering that a relationship is inequitable, individuals are motivated to attempt to restore equity to the relationship. ${ }^{88}$ This is true, not only for participants in the relationship, but also for impartial observers, such as jurors or other legal factfinders. "When participants are unable--or refuse-to restore equity, impartial observers often intervene and attempt to set things right." ${ }^{\text {"99 }}$ Thus, civil verdicts may reflect, in part, decision makers' attempts to restore moral balance to the relationship between the parties.

In affirming the proper moral balance between the parties, civil sanctions may restore corrective justice by adjusting "an unjustified state of affairs between an injurer and a victim, when the injurer's activity has caused the injustice, so that such changes bring about a just state of affairs between them, and one that is related in a morally appropriate way to the status quo ante. ${ }^{90}$ Interestingly, tort litigants themselves may share this restorative goal with jurors. Both tort plaintiffs and tort defendants appear to care as much about receiving dignified and respectful treatment, and a chance to "tell their story," as about the actual monetary outcomes at stake. ${ }^{91}$

${ }^{86}$ See Elaine Walster et al., New Directions in Equity Research, $25 \mathrm{~J}$. PERSONALITY \& SOC. PSYCHOL. 151 (1973).

${ }^{87} I d$.

${ }^{88} I d$.

${ }^{89}$ William Auston et al., Equity and the Law: The Effect of a Harmdoer's "Suffering in the Act" on Liking and Assigned Punishment, 9 ADVANCES EXPERIMENTAL Soc. PSYCHOL. 163, 169 (1976). See also Alan L. Chaiken \& John M. Darley, Victim or Perpetrator?: Defensive Attribution of Responsibility and the Need for Order and Justice, 25 J. PERSONALITY \& SOC. PSYCHOL. 268 (1973).

${ }^{90}$ Radin, supra note 62, at 60.

${ }^{91}$ See E. Allan Lind et al., In the Eye of the Beholder: Tort Litigants' Evaluations of their Experiences in the Civil Justice System, 24 LAW \& SOC'Y REV. 953 (1990); Robert J. MacCoun et al., Alternative Adjudication: An Evaluation of THE NEW JERSEY AUTOMOBILE ARBITRATION PROGRAM (1988). 


\section{Punitive Damages as Restorative}

In one demonstration that jurors may pursue restorative or expressive goals, Michelle Chernikoff Anderson and Robert MacCoun examined the potential influences on juror decision making of whether the punitive damage award is to be paid to the plaintiff or to the state. ${ }^{92}$ While punitive damage awards are traditionally paid to the plaintiff who brought the case, a number of states have passed legislation that allocates some portion of the punitive damage award to the state. ${ }^{93}$ Such legislation responds to concerns that plaintiffs receive a windfall when they receive punitive damage awards that are intended to punish the defendant, in addition to damages intended to compensate them for their losses. ${ }^{94}$

Counter to many commentators' intuition that allocating punitive damages awards to the state will result in an increase in the likelihood and size of such awards, ${ }^{95}$

92 Anderson \& MacCoun, supra note 15.

93 Statutes that allocate punitive damages to the state are often called "splitrecovery" statutes. See, e.g., ALASKA STAT. $\$ 09.17 .020(j)$ (LEXIS 1997) (50\% to general state fund); GA. CODE ANN. $\$ 51-12-5.1(\mathrm{e})(2)$ (2000) (in products liability actions, 75\% less costs and fees to Office of the Treasury and Fiscal Services) (see State v. Moseley, 436 S.E.2d 632 (Ga. 1993), cert. denied 511 U.S. 1107 (1994) (upholding statute)); 735 ILL. COMP. STAT. 2-1207 (1992) (court may apportion award among plaintiff, plaintiff's attorney and State Department of Human Services); IND. CODE ANN. \& 34-51-3-6 (West 1999) (75\% to Violent Crimes Victims Compensation Fund); IOWA CODE ANN. $\S$ 668A.1(2) (West 1998) (under some circumstances, 75\% to civil reparations trust fund); Mo. REV. STAT. § 537.675(3) (West supp. 2003) (50\% to Tort Victims' Compensation Fund); OR. REv. STAT. $\& 18.540$ (1999) (60\% to Criminal Injuries Compensation Account); 73 PA. CONS. STAT. $\$ 2105$ (3) (West 2001) (court has discretion to select organization(s) "engaged in charitable or educational activities involving the fine arts" to receive award); UTAH CODE ANN. \$ 78-18-1(3) (2000) (50\% of amount in excess of $\$ 20,000$ less fees and costs to general state fund). But see Al.A. CODE $\$$ 6-11-21(1) (1999) (no portion of the punitive damage award shall be allocated to the state). Provisions allocating punitive damage awards to the state have been challenged on both state and federal constitutional grounds. For cases upholding split-recovery statutes, see Gordon v. Florida, 608 So. 2d 800 (Fla. 1992); Mack Trucks v. Conkle, 436 S.E.2d 635 (Ga. 1993); Shepherd Components v. Brice Petrides-Donohue \& Associates, 473 N.W.2d 612 (Iowa 1991); Fust v. Missouri, 947 S.W.2d 424 (Mo. 1997); Hoskins v. Business Men's Assurance, 79 S.W.2d 901 (Mo. 2002); DeMendoza v. Huffman, 51 P.3d 1232 (Or. 2002). But see Kirk v. Denver Publ'g Co., 818 P.2d 262 (Colo. 1991) (holding Colorado provision unconstitutional in violation of the takings clauses of the state and federal constitutions).

${ }^{94}$ See Smith v. Wade, 461 U.S. 30, 59 (1982) (Rehnquist, J., dissenting) ("Punitive damages are generally seen as a windfall to plaintiffs, who are entitled to receive full compensation for their injuries-but no more. Even assuming that a punitive 'fine' should be imposed after a civil trial, the penalty should go to the State, not to the plaintiff-who by hypothesis is fully compensated.").

${ }^{95}$ First, it is thought that if punitive damages are awarded to the state, jurors will be relieved of any concern about awarding a windfall to the plaintiff and will feel free to fully punish the defendant. E. Jeffrey Grube, Punitive Damages: A 
Anderson and MacCoun found that mock jurors were more likely to award punitive damages in personal injury cases when they were to be awarded to the plaintiff than when they were to be awarded to the state. ${ }^{96}$ This was true both when the state treasury was to receive the award ${ }^{97}$ and when a consortium of relatively uncontroversial state funds was to receive the award. ${ }^{98}$ Because participants already had an opportunity to compensate the plaintiff through compensatory damages, Anderson and MacCoun suggested that punitive damages serve a symbolic restorative function that is dependent on receipt by the plaintiff. ${ }^{99}$ In such a relational capacity, punitive damages may advance a societal interest in mending the breach caused by the defendant's reprehensible actions. ${ }^{100}$

Misplaced Remedy, 66 S. CAL. L. REV. 839, 855 (1993). Second, because judges and jurors are residents and taxpayers in the states that would be receiving the award, they have some interest in the amount of the award and, accordingly, may award higher amounts in punitive damages than they would if the entire award was to go to the plaintiff. Development in the Law-Jury Determination of Punitive Damages, 110 HARV. L. REv. 1513, 1535 (1997) [hereinafter Jury Determination]; Michelle Riley Stephens, Punitive Damages: Making the Plaintiff Whole or Making the State Wealthy?, 19 AM. J. TRIAL ADVOC. 698, 700 (1996). Moreover, if the portion of the punitive damage award allocated to the state is directed to a state fund which jurors perceive as a "good cause," the temptation, again, may be to increase the punitive damages assessed. Jury Determination, supra, at 1535-36. One commentator stated the intuition thus: "If jurors realized that any punitive damage award were to be returned to public use, the size of the awards would not simply skyrocket. They would follow the Voyager spacecraft out of the solar system." Steven J. Sensibar, Punitive Damages: A Look at Origins and Legitimacy, 41 FED'N INS. \& CORP. COUNS. Q. 375, 387 (1991). Indeed, in response to such concerns, some states do not inform the jury that part of the punitive damage award will go to the state. See, e.g., ALA. CODE § 6-11-21(g) (1999) ("jury may neither be instructed nor informed"); lND. CODE ANN. § 34-51-3-3 (West 1999) (the jury may not be informed of the allocation of punitive damage awards). But see Shari Seidman Diamond \& Jonathan D. Casper, Blindfolding the Jury to Verdict Consequences: Damages, Experts, and the Civil Jury, 26 LAW \& SoC'Y REv. 513, 518 (1992) (discussing the consequences of keeping information from the jury).

${ }^{*}$ Anderson \& MacCoun, supra note 15, at 320-21 (finding, however, no differences in the size of awards).

${ }^{97}$ Id. (study 1 ).

${ }^{98}$ Id. at 325 (study 2). The charities used were adapted from the tax donation charities listed on the 1995 California state income tax form: State Children's Trust Fund for the Prevention of Child Abuse; California Breast Cancer Research Fund; California Firefighters' Memorial Fund; California Public School Library Protection Fund; and California Infectious Disease Research Fund. Id. at 323.

${ }^{89}$ Id. at 326-27. See also G. Bazemore and M. Umbreit, Rethinking the Sanctioning Function in Juvenile Court: Retributive or Restorative Responses to Youth Crime, 41 CRIME \& DELINQ. 296 (1995).

${ }^{100}$ Jonathan Baron \& Ilana Ritov, Intuitions about Penalties and Compensation in the Context of Tort Law, 7 J. RISK \& UNCERTAINTY 17, 25 (1993) (finding that twenty-four of eighty-three participants awarded greater amounts of compensation when the money was to be paid directly to the plaintiff than when a penalty was to go to the government who would then compensate the injured party (only four participants paid less)). They conclude that "many people assign 
Writing about a non-commodified conception of compensation, Radin suggests that compensation can serve to restore the moral balance between the parties by "symboliz[ing] public respect for rights and public recognition of the transgressor's fault by requiring something important to be given up on one side and received on the other, even if there is no equivalence of value possible." ${ }^{\text {101 }}$ Similarly, a punitive damages award, specifically required to be paid by the wrongdoer to the injured party, may affirm the appropriate value of the injured party vis-à-vis the wrongdoer.

\section{Apologies}

While the payment of money by the defendant to the plaintiff may sometimes serve the expressive purpose of reestablishing respect for the victim of wrongdoing, it may not always be the only or the most satisfactory pathway for accomplishing this goal. At least in some contexts, "the medium of monetary damages has very limited expressive power," ${ }^{, 102}$ and may suggest an inappropriate valuing of the victim. ${ }^{103}$

An alternative mechanism by which the appropriate moral balance between the parties can be restored is an apology given by the wrongdoer to the victim. Indeed, equity theorists have suggested that one possible means through which equity might be restored to the relationship between the parties is for the wrongdoer to offer an apology. ${ }^{104}$ To apologize is to engage in a social "ritual whereby the wrongdoer can symbolically bring himself low (or raise us up)." Cohen suggests that, in some cases, "[p]aying monetary damages may help take care of the financial consequences of an injury, but it may take an apology to 'wipe the moral ledger' clean and construct an understanding of the injury and the relationship which both parties can accept."106

compensation not in terms of the injury but rather in terms of setting the balance right between the injurer, if any, and the victim." Id. at 31.

${ }^{101}$ Radin, supra note 62 , at 69.

102 Galanter \& Luban, supra note 4, at 1439 (suggesting that juries provide an explanation for their punitive damages, to spell out the retributive message).

${ }^{103}$ See Sunstein, supra note 20, at 2036 ("A complex network of social norms governs the acceptable uses of money.").

104 Walster et al., supra note 86.

105 Murphy, supra note 79, at 28.

106 Jonathan R. Cohen, Advising Clients to Apologize, 72 S. CAL. L. REV. 1009, 1020 (1999). Intuitively, it seems central to an apology that the apology be offered to the injured party. See Damon Hack, Moss Sorry for Car Incident, N.Y. TIMES, Sept. 27, 
Accordingly, as sociologist Nicholas Tavuchis recognizes,

[g]enuine apologies . . . may be taken as the symbolic foci of secular remedial rituals that serve to recall and reaffirm allegiance to codes of behavior and belief whose integrity has been tested and challenged by transgression, whether knowingly or unwittingly. An apology thus speaks to an act that cannot be undone but that cannot go unnoticed without compromising the current and future relationship of the parties, the legitimacy of the violated rule, and the wider social web in which the participants are enmeshed. ${ }^{107}$

Similarly, Hampton argues that, "by apologizing, we deny the diminishment of the victim, and our relative elevation, expressed by our wrongful action." ${ }^{108}$ In this way, an apology offered by the transgressor to the victim may repair the breach created by the wrongful conduct and affirm the relative value of the parties. ${ }^{109}$

Indeed, experimental studies of apologies in non-legal contexts have found that apologies, or other expressions of remorse, affect decision making in numerous ways, influencing attributions of responsibility for the incident, beliefs about the stability of the behavior (i.e., its likelihood of recurrence), perceptions of the character of the wrongdoer, affective reactions such as anger and sympathy, and behaviors such as forgiveness, aggression and recommendations for punishment. ${ }^{110}$ In addition, experimental studies of reactions to

2002, at D8 (describing football player Randy Moss' apology to those close to him, but not to the traffic agent who he struck).

${ }^{107}$ Nicholas Tavuchis, MEA Culpa: A Sociology OF APOlOGY AND RECONCILIATION 13 (1991).

${ }^{108}$ Hampton, supra note 76 , at 1698-99.

${ }^{109}$ Recently, a number of commentators have argued that apologies may prevent litigation and promote settlement. See Cohen, supra note 106; Deborah L. Levi, The Role of Apology in Mediation, 72 N.Y.U. L. REv. 1165 (1997); Aviva Orenstein, Apology Excepted: Incorporating a Feminist Analysis into Evidence Policy Where You Would Least Expect It, 28 Sw. U. L. REV. 221 (1999). See also Lee Taft, Apology Subverted: The Commodification of Apology, 109 YALE L.J. 1135 (2000). For empirical studies of the effects of apologies on settlement see Russell Korobkin \& Chris Guthrie, Psychological Barriers to Litigation Settlement: An Experimental Approach, $93 \mathrm{MICH}$. L. REV. 107 (1994); Jennifer K. Robbennolt, Settlement, Apologies, and the Rules of Evidence (May 2002) (unpublished paper presented at the Law and Society Association Annual Meeting, Vancouver, B.C.)

110 See Mark Bennett \& Deborah Earwaker, Victim's Response to Apologies: The Effects of Offender Responsibility and Offense Severity, 134 J. Soc. PSYCHOL. 457 (1994); Donald E. Conlon \& Noel M. Murray, Customer Perceptions of Corporate Responses to Product Complaints: The Role of Explanations, 39 ACAD. MGMT. J. 1040 (1996); Bruce W. Darby \& Barry R. Schlenker, Children's Reactions to Apologies, 43 J. Personality \& Soc. Psychol. 742 (1982); Bruce W. Darby \& Barry R. Schlenker, Childrens' Reactions to Transgressions: Effects of the Actor's Apology, Reputation, and Remorse, 28 BRIT. J. SOC. PSYCHOL. 353 (1989); Gregg J. Gold \& Bernard Weiner, 
criminal defendants have generally shown that remorseful defendants are perceived more positively and sentenced more leniently than are defendants who do not show remorse. ${ }^{111}$ Similarly, the only experimental study of remorse in a civil case found that defendants in civil trials who show remorse were perceived more positively than those who did not. ${ }^{112}$ Remorse did not, however, appear to substitute for compensatory damages. ${ }^{113}$

Remorse, Confession, Group Identity, and Expectancies About Repeating a Transgression, 22 BASIC \& APPLIED SOC. PSYCHOL. 291 (2000); Marti Hope Gonzales et al., Victims as "Narrative Critics:" Factors Influencing Rejoinders and Evaluative Responses to Offenders' Accounts, 20 Personality \& Soc. PsychOL. BULL. 691 (1994); Ken-ichi Ohbuchi et al., Apology as Aggression Control: Its Role in Mediating Appraisal of and Response to Harm, 56 J. PERSONALITY \& SOC. PSYCHOL. 219 (1989); Ken-ichi Ohbuchi \& Kobun Sato, Children's Reactions to Mitigating Accounts, $134 \mathrm{~J}$. SoC. Psychol. 5 (1994); Steven J. Scher \& John M. Darley, How Effective are the Things People Say to Apologize? Effects of the Realization of the Apology Speech Act, $26 \mathrm{~J}$. PsYCHOLINGUiSTIC RES. 127 (1997); Gary S. Schwartz et al., The Effects of PostTransgression Remorse on Perceived Aggression, Attributions of Intent, and Level of Punishment, 17 BRIT. J. SOC. \& ClinICAL PSYCHOL. 293 (1978); Bernard Weiner et al., Public Confession and Forgiveness, 59 J. PERSONALITY 281 (1991).

${ }^{111}$ See Michael G. Rumsey, Effects of Defendant Background and Remorse on Sentencing Judgments, 6 J. APPLIED SOC. PSYCHOL. 64 (1976) (finding that participants gave a defendant in a drunk driving case who was described as "extremely remorseful" a shorter sentence than they did a defendant who gave "no indication of remorse"); Christy Taylor \& Chris L. Kleinke, Effects of Severity of Accident, History of Drunk Driving, Intent, and Remorse on Judgments of a Drunk Driver, 22 J. APPLIED SoC. PSYCHOL. 1641 (1992) (finding that a defendant who expressed remorse was rated as being a person of greater responsibility and sensitivity than a defendant who did not express remorse, but not finding significant differences in sentences); Chris L. Kleinke et al., Evaluation of a Rapist as a Function of Expressed Intent and Remorse, $132 \mathrm{~J}$. SOC. PSYCHOL. 525 (1992) (finding that a convicted rapist was judged to have acted less intentionally, to be of less negative character and to have more potential for rehabilitation if he demonstrated remorse than if he did not. Moreover, recommended sentences were predicted by perceived remorse); Randolph B. Pipes \& Marci Alessi, Remorse and a Previously Punished Offense in Assignment of Punishment and Estimated Likelihood of a Repeated Offense, 85 PSYCHOL. REP. 246 (1999). For some boundary conditions on these types of effects see Keith E. Neidermeier et al., Exceptions to the Rule: The Effects of Remorse, Status, and Gender on Decision Making, $31 \mathrm{~J}$. APPLIED SOC. PSYCHOL. 604 (2001). Interviews with jurors in capital cases also provide evidence that the degree to which jurors perceived defendants to be remorseful influenced their choice between a sentence of life in prison and death. See Theodore Eisenberg et al., But Was He Sorry? The Role of Remorse in Capital Sentencing, 83 CORNELL L. REv. 1599 (1998).

${ }^{112}$ Brian Bornstein et al., The Effects of Defendant Remorse on Mock Juror Decisions in a Malpractice Case, 20 BEHAV. SCI. \& L. 393 (2002). In his first study, Bornstein found that remorse had a significant positive effect on jurors' overall perceptions of the defendant. Id. at 400 . In a second study, Bornstein found that defendants who expressed remorse were perceived as having suffered more than defendants who did not express remorse. Id. at 404.

${ }^{113}$ Id. at 404 . In the first study, male participants awarded marginally less in damages against the defendant, a physician, who expressed remorse at the time of trial or who did nothing to indicate remorse or lack thereof, than they did against defendants who were remorseless or who expressed remorse early (at the time of the 
Thus, while offering an apology may not be the best mechanism by which to achieve compensation, it may be a better mechanism by which to express the proper relative moral positions of the parties than is a monetary award. To the extent that a voluntarily offered apology has restored equity between the parties in whole or in part, decision makers may view and use the sanctioning options available to them differently. Similarly, if civil decision makers were allowed to compel an apology as part of their verdict, they might choose to do so as a better way by which to restore equity. ${ }^{114}$

To the extent that the transgressor's wrongful conduct has conveyed the message that the offender considers the victim to be beneath her, an apology, voluntary or compelled, serves as a degradation ceremony that restores equal footing between victim and offender. If the apology involves a public expression of remorse, it may address the loss of face that the victim has suffered in front of the witnessing community. Moreover, the victim may see an apology that is enforced by a judgmental body, even if insincere, as a community statement that the victim is not to be treated as less valuable than others. The apology, then, sends a signal to the offender, the victim and the community that the victim is a valued and defended member of the community who cannot be treated in a fashion that diminishes her worth.

incident). For female participants, remorse had no effect on damage awards. Id. at 399400. In a second study, participants awarded more in compensatory damages against the defendant, who displayed remorse at the time of the event and then again at the time of trial, than they did in the other three conditions. Id. at 403. Given potential spillover between liability and damages decisions, it is unclear how these results might have been affected by telling jurors to assume that the defendant was liable. It is possible that jurors used the available decision to achieve goals that might otherwise have been achieved through the rendering of a liability verdict.

${ }^{114}$ See, e.g., Richard Monastersky, Former History Professor Wins \$5.3-Million Verdict Against Fairleigh Dickinson U., CHRON. HIGHER EDUC., May 21, 2001 (describing a jury that asked the defendant to "offer a formal written apology" to the plaintiff). Civil jurors, however, do not typically have the ability to compel an apology from the defendant to the plaintiff. The First Amendment raises potential obstacles to compelled apologies in civil cases. See Wooley v. Maynard, 430 U.S. 705, 714 (1977) ("[T]he right of freedom of thought protected against state action includes both the right to speak freely and the right to refrain from speaking at all."). See also Griffith v. Smith, 30 Va. Cir. 250 (1993) ("First Amendment concerns preclude the Court from ordering the apology originally suggested."); Imperial Diner, Inc. v. State Human Rights Appeal Bd., 417 N.E.2d 525 (N.Y. 1980). 


\section{LEGAL DECISION MAKING AS CONSTRAINT SATISFACTION}

The above theories and studies suggest that legal decision makers make decisions that may reflect a variety of expressive goals in addition to other goals, including those contained in legal theory, that they hope to achieve. Accounts of legal decision making that ignore these expressive motives are likely to be inadequate. In addition, any account of legal decision making that portrays decision makers as having singular goals is likely to be insufficient. Thus, for example, accounts of legal decision making premised on decision makers being solely concerned with effecting optimal deterrence are unlikely to capture important aspects of the decision-making task. ${ }^{115}$ Similarly, an account based solely on a picture of decision makers pursuing only expressive goals will miss important parts of the picture. Accordingly, accounts of legal decision making should comprise the variety of considerations that decision makers might bring to bear on their verdicts.

To this end, legal decision making might profitably be conceived of as a process of parallel constraint satisfaction that can be represented using connectionist models. ${ }^{116}$ These models attempt to simulate situations in which the decision maker must integrate numerous "mutually interacting" elements (e.g.,

115 See Sunstein et al., supra note 16; Baron \& Ritov, supra note 100; and Viscusi, supra note 7 for evidence that jurors do not always effect optimal deterrence. See also Galanter \& Luban, supra note 4 , at 1450 (“[C]itizens and legislators may rightly insist that they are willing to tolerate some loss in economic efficiency in order to deter what they consider morally offensive conduct, albeit cost-beneficial morally offensive conduct: efficiency is just one consideration among many.").

116 See generally CONNECTIONIST MODELS OF SOCIAL REASONING AND Social BEHAVIor (Stephen J. Read \& Lynn C. Miller eds., 1998). See also Stephen J. Read et al, Connectionism, Parallel Constraint Satisfaction Processes, and Gestalt Principles: (Re)Introducing Cognitive Dynamics to Social Psychology, 1 PERSONALITY \& SoC. PSYCHOL. REV. 26 (1997) ("Connectionism, neural networks, and parallel distributed processing models are among the fastest growing research areas in the study of the mind."). There are other theoretical traditions in psychology that might also be invoked to characterize goal multiplicity and goal conflict, including the psychodynamic (or Freudian) approach, the cognitive consistency approach (including cognitive dissonance theory) and the control theory or cybernetic approach. Interestingly, the constraint satisfaction approach appears to capture important insights from all three traditions. See Paul Thagard \& Josef Nerb, Emotional Gestalts: Appraisal Change and the Dynamics of Affect, 6 PersonalitY \& SOC. PSYCHOL. REV. 274 (2002); Dan Simon \& Keith J. Holyoak, Structural Dynamics of Cognition: From Consistency Theories to Constraint Satisfaction, 6 Personality \& SoC. Psychol. REV. 283 (2002); Charles S. Carver \& Michael F. Scheier, Control Processes and Self-Organization as Complementary Principles Underlying Behavior, 6 PERSONALITY \& SOC. PSYCHOL. REV. 304 (2002). 
pieces of evidence, concepts, propositions or goals), that may or may not be consistent, into a coherent whole. ${ }^{117}$

\section{A. Parallel Constraint Satisfaction}

When decision making is thought of as a constraint satisfaction network, the factors related to the decision are conceived of as nodes or elements in a neural-like network. Depending on the decision-making task, these elements can be pieces of evidence, propositions, concepts, goals and so on. ${ }^{118}$ Elements are connected by links that are weighted (indicating the strength of the link) and valenced (indicating the coherence or incoherence between the elements). The valence of the link represents the extent to which the elements constrain or reinforce each other. Elements may be coherent; that is, they are mutually supportive of each other. In contrast, elements may be incoherent, or negatively associated. ${ }^{119}$ Thus, if one element explains or facilitates another element, the link between them will be positively valenced. Conversely, elements that are incompatible or that inhibit each other will be connected by negatively valenced links. ${ }^{120}$ For example, one person might be observed hitting another in the shoulder. The blow might either be interpreted as a violent strike or as a friendly cuff. An element representing the blow itself would be positively linked to elements representing each of these interpretations; the elements representing these two inconsistent interpretations, however, would be connected by a negative link.

Decision making, then, is the process by which the "best compromise among the constraints"121 is selected by "dividing a set of elements into accepted and rejected sets in a way that satisfies the most constraints. ${ }^{122}$ This division is achieved based on each element's level of activation (e.g., ranging from -1 to 1 ). In a parallel constraint satisfaction connectionist

117 CONNECTIONIST MODELS OF SOcIal REaSoning AND SOCIAL BeHavioR, supra note 116, at vii.

${ }^{118}$ Read et al., supra note 116, at 29 ("What the nodes and links represent depends on the theoretical assumptions of a specific model." ${ }^{n}$.

119 Id. at 28; PAUL THAGARD, CoHerence IN THOUGHT AND ACTION 17 (2000).

${ }^{120}$ Read et al., supra note 116, at 28; THAGARD, supra note 119, at 17.

${ }^{121}$ Stephen J. Read \& Amy Marcus-Newhall, Explanatory Coherence in Social Explanations: A Parallel Distributed Processing Account, 65 J. PERSONALITY \& Soc. PSYCHOL. 429, 431 (1993).

${ }^{122}$ THAGARD, supra note 119 , at 17. 
model, each element is assigned an equal initial activation value (e.g., .01) ${ }^{123}$ The central aspect of the model is that the activation level of each element in the model is then updated simultaneously based on four factors: (1) the number of other elements connected to it; (2) the level of activation of those elements; (3) the strength of the links to these other elements; and (4) the valence of those links. ${ }^{124}$ This updating process is iterated with activation of elements spreading through the network based on the configuration of links between the elements until the activation of each element stabilizes. ${ }^{125}$ Once the network settles, each element is accepted or rejected based on its final degree of activation. ${ }^{126}$

In this way, a parallel constraint satisfaction model "simultaneously solves for a set of constraints among a set of concepts." 127 As Stephen Read, Eric Vanman and Lynn Miller describe it:

When activation spreads through such a network, nodes with positive links will tend to activate each other and nodes with negative links will inhibit each other. Because the activation of a node is a result of all of its positive and negative links to other nodes, the final activation of the node can be thought of as a solution to all the constraints represented by the links. Moreover, because activation is spread in parallel among all the connected nodes, this process results in a global solution to the constraints among the entire set of nodes. ${ }^{128}$

This basic model, in which multiple, complexly related elements are simultaneously integrated in parallel to achieve a coherent decision, "is general enough to be applicable to any judgment task that requires the integration of many sources of

${ }^{123} I d$. at 30-31. Within the model, it is possible to link favored elements (such as empirical data) to an element that is set at a maximum activation. This gives priority to those elements, at least initially, as the model updates. Id.

${ }^{124}$ Read et al, supra note 116 , at 29.

125 Id. at 27-28; THAGARD, supra note 119, at 30-31. Read et al., supra note 116 , at 37 (" $[O]$ ne way to view what is happening is that this is an attempt to minimize the degree of tension or conflict .... given the constraints imposed by the actual set of relations among the cognitive elements.").

${ }^{126}$ THAGARD, supra note 119, at 30-31 (describing how elements are accepted if activation is above specified threshold).

${ }^{127}$ Read et al., supra note 116 , at 27.

${ }^{128}$ Id. at 29. See also Read \& Marcus-Newhall, supra note 121, at 431 ("The greater the number of excitatory links to a concept and the greater the strength of the links, the higher the activation of that concept. Conversely, the greater the number of inhibitory links and the greater their strength, the lower the activation of that concept. By this process, concepts that are not supported by other concepts die out, and concepts that are supported are strengthened."). 
information." ${ }^{129}$ Thus, it is a useful model with which to understand legal decision making. ${ }^{130}$ First, legal decision makers engage in constraint satisfaction with regard to the story they select to account for the evidence presented at trial (explanatory coherence). Second, decision makers attempt to select verdicts that maximize satisfaction of their goals (deliberative coherence). ${ }^{131}$ We explore these possible applications of the basic parallel constraint satisfaction model below.

\section{B. Explanatory Coherence}

A parallel constraint satisfaction model of explanatory coherence is particularly useful for understanding how legal decision makers select a story that represents what happened in a case, integrating the numerous pieces of potentially

129 Ziva Kunda \& Paul Thagard, Forming Impressions From Stereotypes, Traits, and Behaviors: A Parallel-Constraint-Satisfaction Theory, 103 PSYCHOL. REV. 284, 304 (1996). See, e.g., Keith J. Holyoak \& Paul Thagard, Analogical Mapping by Constraint Satisfaction, 13 CoGNITIVE SCI. 295 (1989) (analogical mapping); W. Kintsch, The Role of Knowledge in Discourse Comprehension: A ConstructionIntegration Model, 95 PSYCHOL. REV. 163 (1988) (discourse comprehension); D. Marr \& T. Poggio, Cooperative Comutation of Stereo Disparity, 194 ScIEnce 283 (1976) (stereoscopic vision); James L. McClelland \& David E. Rumelhart, An Interactive Activation Model of Context Effects in Letter Perception: Part I. An Account of Basic Findings, 88 PsYCHOL. REV. 375 (1981) (letter perception); Walter Mischel \& Yaichi Shoda, A Cognitive-Affective System Theory of Personality: Reconceptualizing Situations, Dispositions, Dynamics, and the Invariance in Personality Structure, 102 PSYCHOL. REV. 246 (1995) (understanding personality traits); T.R. Schultz \& M.R. Lepper, A Constraint Satisfaction Model of Cognitive Dissonance Phenomena, in PROCEEDINGS OF THE FOURTEENTH ANNUAL CONFERENCE OF THE COGNITIVE SCIENCE SOCIETY 462 (1992) (dissonance reduction).

${ }^{130}$ In 1992, Thagard noted the close parallels between his constraint satisfaction model of explanatory coherence and the influential "story model" of juror cognition. See PAUL THAGARD, ConCePTUAL ReVolutions (1992); Nancy Pennington \& Reid Hastie, Explaining the Evidence: Tests of the Story Model for Juror Decision Making, 62 J. PERSONALITY \& SOC. PSYCHOL. 189 (1992). See also infra notes 136-39 and accompanying text. Another recent application of constraint satisfaction to legal decision making is the research program of Simon and Holyoak. See Keith J. Holyoak \& Dan Simon, Bidirectional Reasoning in Decision Making by Constraint Satisfaction, 128 J. EXPERIMENTAL PSYCHOL.: GENERAL 3 (1999); Simon \& Holyoak, supra note 116.

${ }^{131}$ While our remarks here focus on the decisions of individual decision makers, the concepts involved in parallel constraint satisfaction networks can be extended to model decisions by groups such as juries. For example, Thagard describes a model of consensus decision making in which

[c]onsensus arises when individuals in a group exchange information to a sufficient extent that they come to make the same coherence judgments about what to accept and what to reject. The information exchange involves both elements to be favored in a coherence evaluation . . . and descriptions of the explanatory and other relations that hold between elements.

THAGARD, supra note 119 , at $225-26$. 
contradictory evidence presented at trial. ${ }^{132}$ In a model of explanatory coherence, decision makers "construct an interpretation that fits with the available information better than alternative interpretations." ${ }^{\text {"133 }}$ As Paul Thagard explains, "the best interpretation is one that provides the most coherent account of what we want to understand, considering both pieces of information that fit with each other and pieces of information that do not fit with each other." ${ }^{134}$

In a connectionist model of the theory of explanatory coherence applied to legal decision making, the elements in the model are the evidence presented and propositions, explanations or hypotheses about this evidence. The links between the elements are based on "relations of explanation and analogy that hold between propositions." ${ }^{\text {135 }}$ For example, a hypothesis would have a positive link to a piece of evidence that it explains and a negative link to a contradictory hypothesis; contradictory pieces of evidence would be connected by a negative link. In a connectionist model, the activation of the elements is updated in parallel until the network iteratively converges on a configuration of activated elements that represents maximal satisfaction of the constraints imposed. Decision makers then choose the account or story that has the best coherence as indicated by the final pattern of activation among the elements.

This process of parallel constraint satisfaction is consistent with psychological understanding of juror decision making. In making sense of contradictory facts and testimony presented at trial and different explanations for the evidence presented by the opposing sides, jurors are often called upon to accept an account that best fits with the available evidence. ${ }^{136}$ Pennington and Hastie's story model of juror decision making proposes that jurors: (1) construct and evaluate narrative stories of the events at issue based on the information

${ }^{132}$ Paul Thagard \& Ziva Kunda, Making Sense of People: Coherence Mechansims, in CONNECTIONIST MODELS OF SOCIAL REASONING AND SOCIAL BEHAVIOR, supra note 116, at 3 ("Processes of maximizing explanatory coherence are particularly well-suited for accounting for jury decision making, where the task is to evaluate the coherence of accounts presented by the prosecution and the defense.").

133 THAGARD, supra note 119 , at 16 .

134 Id.

135 Id. at 21

${ }^{136}$ Read \& Marcus-Newhall, supra note 121, at 429 ("We suggest that part of what people do in trying to explain such a sequence of behaviors is to try to find the explanation that best fits or is the most coherent with the events to be explained."). 
presented at trial; (2) learn the verdict alternatives; and (3) match the story that they have accepted to the appropriate verdict. ${ }^{137}$ The coherence of each proposed account or story is integral to its acceptability: While multiple stories may be considered, a more coherent story is more likely to be accepted. ${ }^{138}$ Connectionist models provide a formal structure for the mechanism by which the coherence of different stories is evaluated. Recently, these types of parallel constraint satisfaction models have been applied to explain decisions in both mock jury experiments and in actual jury trials. ${ }^{139}$

\section{Deliberative Coherence}

Another way in which parallel constraint satisfaction models could be applied to legal decision making is more central to our point here. In a model of deliberative coherence, decision makers both evaluate potentially inconsistent goals and select actions to perform, "with the desirability of actions and goals determined by a judgment of . . . deliberative coherence," that is, the degree to which the system of interconnected actions and goals cohere. ${ }^{140}$ As Thagard explains:

In brief, decision making is inference to the best plan. When people make decisions, they do not simply choose an action to perform, but rather adopt complex plans on the basis of a holistic assessment of various competing actions and goals. Choosing a plan is in part a matter of evaluating goals as well as actions. Choice is made by

${ }^{137}$ Nancy Pennington \& Reid Hastie, Evidence Evaluation in Complex Decision Making, 51 J. PERSONALITY \& SOC. PSYCHOL. 242 (1986); Nancy Pennington \& Reid Hastie, Explanation-Based Decision Making: Effects of Memory Structure on Judgment, 14 J. EXPERIMENTAL Psychol.: LEARNING, MEMORY, \& CoGNition 521 (1988); Pennington \& Hastie, supra note 130. See, e.g., Pennington \& Hastie, supra note 17, at 198 fig. 8.1 .

138 Pennington \& Hastie, supra note 130 , at 198.

139 See Holyoak \& Simon, supra note 130; Dan Simon, A Psychological Model of Judicial Decision Making, 30 RUTGERS L.J. 1 (1998); Paul Thagard, Explanatory Coherence, 12 BEHAV. \& BRAIN SCI. 435 (1989) (using ECHO computer program to model reasoning in two actual murder trials); Michael D. Byrne, The Convergence of Explanatory Coherence and the Story Model: A Case Study in Juror Decisions, in Proceedings of The 17Th ANNuAl Conference of THE Cognitive Science SocieTy (Johanna D. Moore \& Jill Fain Lehman eds., 1995) (using ECHO to model decisions of subjects from Pennington \& Hastie's 1993 study, cited supra note 17). See also Stephen J. Read \& Lynn C. Miller, Rapist or "Regular Guy": Explanatory Coherence in the Construction of Mental Models of Others, 19 PERSONALITY \& SOC. PSYCHOL. BULL. 526 (1993).

140 Paul Thagard \& Elijah Millgram, Inference to the Best Plan: A Coherence Theory of Decision, in GOAL-DRIVEN LEARNING 439, 439-40 (Ashwin Ram \& David B. Leake eds., 1995). 
arriving at a plan or plans that involve actions and goals that are coherent with other actions and goals to which one is committed. ${ }^{141}$

Parallel constraint satisfaction modeling of deliberative coherence provides a formal model for how decision makers "mediate among the influence of multiple, salient, and often conflicting goals and do so in a way that results in reasonable behavior that is sensitive both to the desires of the individual and the opportunities and constraints of the environment."142

In the context of civil cases, we suggest that decision makers attempt to reach a decision that balances multiple, potentially inconsistent goals and fits within the constraints of the legal decision-making task (e.g., jury instructions, verdict options, etc.). Just as parallel constraint satisfaction models of explanatory coherence frame the way in which legal decision makers map the trial evidence onto a coherent story and match that story to the verdict options, we propose that parallel constraint satisfaction models of deliberative coherence can frame the way in which legal decision makers map their myriad goals onto the available verdict options.

The elements in such a connectionist model of deliberative coherence are actions and goals. The links between these elements are based on whether they facilitate or inhibit each other, or are compatible or incompatible, and the degree to which this is so. ${ }^{143}$ For example, the goal of engaging in moral cleansing may be connected by a positive link to the action of awarding a particular dollar amount, while the goal of appropriately compensating the plaintiff may be connected by a negative link to that same dollar award.

It is useful to think of these links as implementing the goal management principles described earlier. For example, a goal might be connected by positive links to more than one action (equifinality) and each possible action may be connected by positive links to more than one goal (multifinality). At the same time, the links between a goal and several different

${ }^{141} I d$. at 440 (describing deliberative coherence as "an account of the nature of human decision making that we think is more psychologically realistic than classical decision theory").

${ }^{142}$ Read et al., supra note 116, at 47 (describing deliberative coherence generally). For a thorough discussion of deliberative coherence see Thagard \& Millgram, supra note 140. See also Suzanne M. Mannes \& Walter Kintsch, Routine Computing Tasks: Planning as Understanding, 15 CoGNITIVE SCI. 305 (1991) (describing model of goal-directed behavior based on parallel constraint satisfaction).

143 Thagard \& Millgram, supra note 140. 
actions may have different weights (best fit) and some of the links between two goals or two actions may be negatively valenced (incompatibility). The connectionist network updates activation of the elements (goals and actions) in parallel until the network stabilizes. In this case, the final activation of the elements represents the decision maker's chosen set of selected actions and goal valuations. ${ }^{144}$

While distinct from explanatory coherence, deliberative coherence is connected to explanatory coherence. Any of the many "[f] acilitative and competitive relations [among actions and goals] may often depend on the coherence of the goals and actions with factual beliefs, which indicate the degree of facilitation or inhibition that is believed to be the case. ${ }^{1145}$ Thus, the deliberative coherence of an action taken (e.g., a particular dollar award) to further a given goal (e.g., deterrence) depends in part on the explanatory coherence of the judgment that that action will facilitate the desired goal (e.g., beliefs about the degree to which the dollar award will in fact deter the defendant).

A simplified example illustrates these relationships. Imagine a decision maker has determined that a defendant is liable for a plaintiff's injuries and is attempting to determine whether a monetary award in the amount requested by the plaintiff or in the amount recommended by the defendant would be more appropriate. Imagine further that the decision maker has only the following goals: to express disapproval of the behavior, to cover the plaintiff's out-of-pocket expenses, and to not overcompensate the plaintiff. Figure 1 below represents these verdict options and decision maker goals in one possible connectionist framework. Solid lines represent compatible relationships and broken lines represent incompatible relationships. The decision maker might believe that either award would cover the plaintiff's expenses (equifinality), but that the larger amount would overcompensate the plaintiff (incompatibility). At the same time, the decision maker may

${ }^{144}$ Id. at 444 . See also Read et al., supra note 116 , at 49 (“TTlhe decision maker is predicted to choose the set of actions and goals that are most coherent and have the highest levels of activation. Actions and goals with high levels of activation are part of the plan to be performed."). In order to account for the "intrinsic desirability of some goals," goals may be linked to units that begin with different levels of activation to indicate "different degrees of desirability." Thagard \& Millgram, supra note 140 , at 444 .

${ }^{145}$ Read et al., supra note 116, at 49; Thagard \& Millgram, supra note 140, at 442; THAGARD, supra note 119 , at $129-30$. 
believe that either amount would serve to express disapproval (equifinality), but believe that the larger amount may better convey this disapproval (best fit). Thus, the smaller award would serve to cover the plaintiff's expenses while not overcompensating the plaintiff, and would express to some degree the decision maker's disapproval of the defendant's behavior (multifinality). Yet, the larger award would serve to cover the plaintiff's expenses and would strongly express disapproval (multifinality), but would overcompensate the plaintiff (incompatibility). The decision maker would choose the award that best satisfies the various goals based on the strength of each goal, the relationships between the goals and the verdict options and the decision maker's beliefs about effectiveness of each verdict option for satisfying each goal (explanatory coherence). ${ }^{146}$

This conceptualization of legal decision making suggests that decision makers faced with different arrays of verdict options or possessing different combinations of goals may reach different judgments based on identical bodies of evidence, and it suggests the mechanism by which this could occur. Consistent with this notion, empirical research on punitive damages decision making suggests that changing the available verdict options can affect how decision makers utilize the remaining options to effectuate their goals. ${ }^{147}$ Anderson and MacCoun found that jurors who were not allowed to award punitive damages in response to a personal injury scenario awarded more in pain and suffering than did those who were allowed to make an award of punitive damages. ${ }^{148}$ Similarly, in their recent investigation of limits on punitive damages, Edith Greene, David Coon and Brian Bornstein found that jurors who were not given the opportunity to award punitive damages awarded more in compensatory damages than did jurors who

146 This model is highly simplified; a more sophisticated model would incorporate additional possible verdict options, additional goals and other influences on decision making. Importantly, it is likely that decision makers' judgments about damages are made along a more continuous scale than is suggested by this simplified model. See Kahneman et al., supra note 48; Sunstein et al., supra note 48. A more elaborate modeling effort would be necessary to address these scaling issues. But cf. Bibb Latane, Strength from Weakness: The Fate of Opinion Minorities in Spatially Distributed Groups, in UNDERSTANDING GROUP BEHAVIOR 193 (Erich H. Witte \& James H. Davis eds., 1996).

${ }^{147}$ Correspondingly, changes in the goals the decision maker seeks to fulfill ought to change how the decision maker uses the verdict options to fulfill those goals.

148 Anderson \& MacCoun, supra note 15, at 319-20. 
were allowed to make unrestrained punitive damage awards. ${ }^{149}$ Moreover, they found no differences in the total damages awarded by the two groups. ${ }^{150}$ The results of these studies suggest that decision makers who are blocked from expressing their punitive intent through punitive damages find other mechanisms through which to satisfy their goals (i.e., equifinality). ${ }^{151}$ Similarly, if the defendant had already fulfilled, in whole or in part, one or more of the decision maker's goals, for example, by offering an apology, the decision maker might be expected to make use of the verdict options differently than if no apology were forthcoming or could be compelled. ${ }^{152}$

Thus, just as different accounts of the events in a case compete for acceptance by the finder-of-fact, so too legal decision makers attempt to address multiple goals that compete to be satisfied. Verdict options, including a liability verdict and compensatory and punitive damages, may be used by legal decision makers in their attempts simultaneously to fulfill compensatory, expressive, punishment, deterrence, distributive justice and moral cleansing goals along with other normative and non-normative goals. Conceiving of civil verdicts as the outcome of attempts to use the available verdict options to satisfy these multiple, potentially competing goals in parallel provides a useful model for more thoroughly understanding such decisions.

\section{CONCLUSION}

A multi-motive conception of jurors, in contrast to traditional accounts of decision makers as focused on singular goals, provides a richer picture of the cognitive processing of legal decision making in civil cases. Considering goals that have not been traditionally considered by the law, such as differing notions of distributive justice, expressive and value concerns, reactions to taboo trade-offs and concerns for moral balance between the parties, explains a variety of empirically observed phenomena that are difficult to account for with

149 Greene et al., supra note 19 , at 226.

${ }^{150}$ Id. at 228 (i.e., the compensatory damages awarded by the group not allowed to award punitive damages were no different from the total of the compensatory and punitive damages in the group allowed to award both).

151 Galanter \& Luban, supra note 4, at 1406 ("[T]he legal line between punitive damages and compensatory damages does not accurately demarcate the presence of motives or perceptions of punishment.").

${ }^{152}$ See supra Part II.C.3. 
typical single motive accounts (e.g., the optimal deterrence model). Moreover, insight into how decision makers manage these diverse goals is gained by conceptualizing these multiple goals as interrelated in complex ways according to a set of goal management principles and dealt with through a system of cognitive processing that attempts to satisfy as many of these goals to the greatest extent possible through a process of parallel constraint satisfaction.

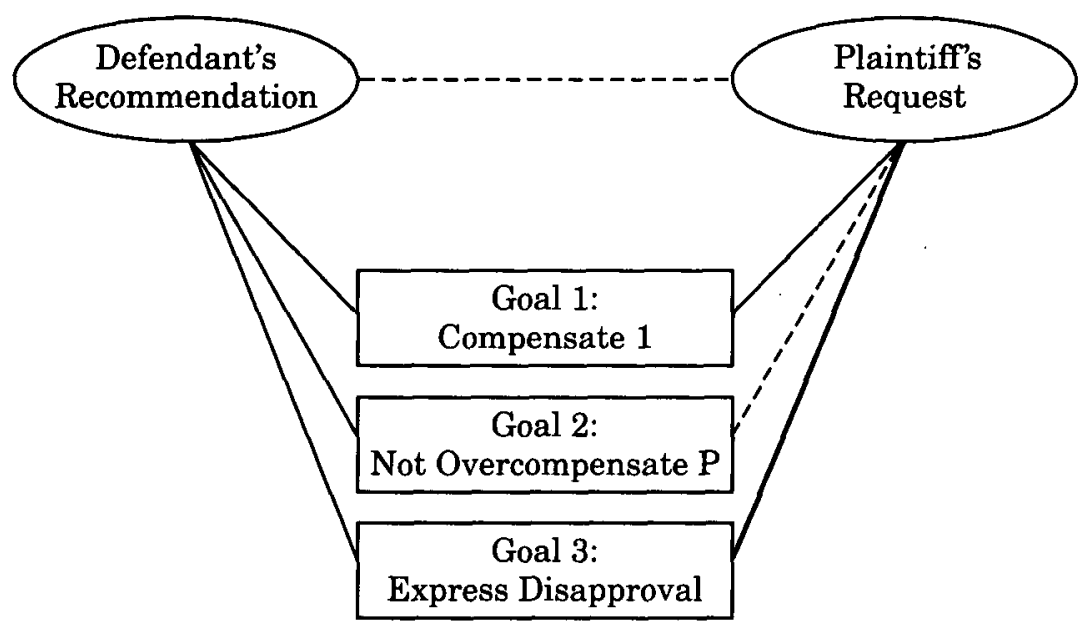

Figure 1: Deliberative Coherence of Decision Goals and Verdict Options 